\title{
Militares, cortesanos y poetas en el entorno de los infantes de Aragón (1439-1445): las Coplas de Juan de Dueñas al infante don Entique
}

Military, courtiers and poets in the environment of the Infantes of Aragon (1439-1445): las Coplas de Juan de Dueñas al infante don Enrique

Agustín Rubio Vela rubiovela@yahoo.es

I. $S$.

Resumen: A la luz de crónicas y documentos del siglo XV, las Coplas de Juan de Dueñas al infante don Enrique, poema de cancionero que constituye una fuente histórica de notable interés para el conocimiento del entorno militar, cortesano y literario de Juan de Navarra, futuro Juan II de Aragón, hubo de ser escrito en Castilla entre 1440 y 1443, años previos a la derrota en Olmedo de los infantes de Aragón.

Palabras clave: Juan de Dueñas, Enrique de Aragón, Juan de Navarra, Juan II de Castilla, siglo XV, infantes de Aragón

\begin{abstract}
The Coplas de Juan de Dueñas al infante don Enrique, a Castilian poem of the 15th century, is a historical source of notable interest to explore the military environment of the time, as well as the court and literary world of John of Navarra, who would later become John II of Aragon. An analysis of its contents, in the light of contemporary chronicles and documents, reveals it must have been written in Castile between 1440 and 1443; that is, prior to the defeat of the Infantes of Aragon in Olmedo.
\end{abstract}

Keywords: Juan de Dueñas, John of Navarra, John II of Castile, Infants of Aragon, 15th century 
Agustín Rubio Vela. Militares, cortesanos y poetas en el entorno de los infantes de Aragón (14391445): las Coplas de Juan de Dueñas al infante don Enrique

Las obras literarias ayudan entender la sociedad en que fueron escritas, del mismo modo que el conocimiento de la sociedad, del contexto histórico en que surgen, resulta indispensable para su comprensión. No por ser evidente resulta superfluo recordar esto al inicio del análisis de una composición del siglo XV, las Coplas de Juan de Duennas al sennor infante don Enrrique, cuyos versos suministran datos de indudable interés histórico, pero no la referencia cronológica clara e incuestionable que permita enmarcarlos en el tiempo con exactitud. Tras haber sido estudiadas por primera vez en 1872 por José Amador de los Ríos, las Coplas volvieron a ser analizadas en la pasada centuria por dos filólogas, Francisca Vendrell (1958) y Nancy Marino (1985), y por un historiador medievalista, Eloy Benito Ruano (1964). Todos ellos se interesaron por este poema castellano, lleno de incógnitas, al que dedicaremos las páginas que siguen con el propósito de aproximarnos con la mayor precisión posible, a la luz de todos datos a nuestro alcance - conocidos unos e inéditos otros-, tanto a su contenido como al contexto en que fue forjado. ${ }^{1}$

\section{El contenido.}

Obligado es indicar desde un principio que estamos ante una composición dirigida, como indica su título, a uno de los llamados «infantes de Aragón», don Enrique, hijo de Fernando I (1412-1416) y hermano de quienes sucedieron a éste en el trono de la Corona de Aragón: Alfonso V el Magnánimo (1416-1458) y Juan II (1458-1479). ${ }^{2}$ Se aprecian en ella dos partes. Una primera en la que el poeta envía reverencialmente saludos al infante, en nombre propio y en el de otras personas — más de diez- que se encontraban en aquellos momentos con él en la corte de Juan, entonces rey de Navarra, su hermano. En la segunda parte, Dueñas informa a don Enrique — desde la distancia, obviamente - de la gracia y belleza de un sobrino suyo, niño de corta edad, cuyas cualidades elogia.

$\mathrm{El}$ autor daba comienzo al saludo colectivo con una interesante referencia a la heroica y sagrada misión de combatir a los infieles que don Enrique tenía, como maestre que era de la orden militar de Santiago desde 1409 (Benito Ruano 1952: 17 y 94-98):

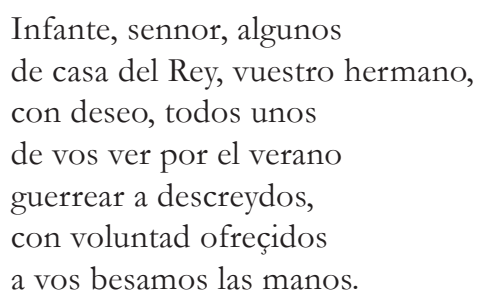

\footnotetext{
1 Sólo se conoce una copia, la del Cancionero de San Roman o de Gallardo (ca. 1454) conservado en la Real Academia de la Historia (signatura: 2/Ms. 2, f. 349r). Fue editado por Francisca Vendrell de Millás (1958: 200) y por Dutton (19901991: 503).

2 «Los Infantes de Aragón fueron hijos de Don Fernando de Antequera, el hermano de Enrique III [de Castilla] que, a la muerte de Don Martín el Humano, sería proclamado en Caspe Rey de Aragón» (Benito Ruano 1952: 11).
}

SCRIPTA, Revista internacional de literatura i cultura medieval i moderna, núm. 9 / juny 2017 / pp. 113-143 ISSN: 2340 - 4841 doi:10.7203/SCRIPTA.9.10214 
Agustín Rubio Vela. Militares, cortesanos y poetas en el entorno de los infantes de Aragón (14391445): las Coplas de Juan de Dueñas al infante don Enrique

Así pues, por medio del poeta, «algunos» hombres físicamente próximos al rey de Navarra, personas de su casa y entorno, besaban las manos de su hermano desde la distancia, y le manifestaban su anhelo por verlo luchar contra los musulmanes a la llegada de la época estival.

¿Quiénes eran esos cortesanos? Los nombres se indican en las dos estrofas que siguen:

Ruy Dias el principal

y Rebolledo con el,

Ferrando de Sandoual,

Juan de Puelles y Martel

los Fajardo y Gueuara,

con voluntad syn ufana

nos terneys por un cordel.

Semenal y Casteluy

y Pacheco syn contienda,

Juan de Duennas otrosy

a vuestro bien se rrecomienda.

Los siguientes tres versos ya son el comienzo del elogio del sobrino de don Enrique:

Y sabed, sy non sabeys,

de un sobrino que teneys

virtuoso syn emienda.

El feliz retrato del niño ocupa el resto de la composición:

Sennor, teneys un sobrino

ante cuya fermosura

çeso Narçiso, y Luquano

ya pereçe su escritura,

que en el mundo no naçio

desque Dios lo formo

tan fermosa criatura.

Pues despues de ser fermoso,

lindo syn conparaçion

guareçe que no es, graçioso,

de gentil conuersaçion,

en verdad, sennor infante,

que no ay persona bastante

a loar su condiçion.

Que sus vertudes son tantas,

syn ninguna manera fea,

syn duda pensamos quantas

no ay persona que las crea,

ni cremos en verdad

ninno de tan poca hedad

que en el mundo su par sea.

Las Coplas terminan con dos deseos del poeta: que tan hermosa criatura llegue a tener sobre su cabeza una corona imperial, y que Dios conceda al infante un hijo adornado de las mismas virtudes que las del sobrino:

SCRIPTA, Revista internacional de literatura i cultura medieval i moderna, núm. 9 / juny 2017 / pp. 113-143

ISSN: 2340 - 4841 doi:10.7203/SCRIPTA.9.10214 
Agustín Rubio Vela. Militares, cortesanos y poetas en el entorno de los infantes de Aragón (14391445): las Coplas de Juan de Dueñas al infante don Enrique

\author{
Fyn \\ El sennor Dios lo prouea \\ de corona inperial, \\ y a vos de fijo atal \\ qual vuestra merçed desea.
}

\title{
2. Los estudios y la cronología.
}

Texto literario, pues, pero también documento de interés histórico, las Coplas dan cuenta, aunque de manera imprecisa, de las personas que rodeaban y eran afectas a Juan de Navarra en un determinado momento, y que a la vez sentían profunda simpatía hacia su hermano Enrique. Ahora bien, el cuándo es una incógnita. De ahí la necesidad de recurrir a la investigación histórica para hacer comprensible el poema, que exige establecer su cronología, averiguar la identidad de los componentes del círculo cortesano más próximo al futuro Juan II de Aragón en un tiempo concreto, y, por supuesto, la identidad del agraciado sobrino de don Enrique, tan encomiásticamente descrito por Dueñas. Hasta ahora, todos los autores han coincidido en este punto: no podía ser otro que Carlos, príncipe de Viana, hijo de Juan y de Blanca, reina de Navarra, en cuya corte habrían sido escritas las Coplas. En cambio, en lo relativo al tiempo no ha habido unanimidad: unos las han situado en 1426, otros en 1428, e incluso, incurriendo en flagrante contradicción, en 1437-1439.

\subsection{Amador de los Ríos y Francisca Vendrell.}

Tal es el caso de José Amador de los Ríos, el primer autor que prestó atención a esta curiosa muestra de poesía política bajomedieval, según el cual habría sido escrita por Dueñas en Navarra hacia los años 1437-1439, antes de que el infante Enrique hubiera vuelto de Italia. Son éstas sus palabras: «Poco tiempo después dirigia desde Navarra al infante D. Enrique, todavía en Italia, otro dezir ó carta poética escrita á la manera provenzal, en que le participaba que él y otros muchos, sus devotos y parciales, le estaban esperando para renovar sus empresas y correrías de antaño». A propósito de la descripción ditirámbica del príncipe Carlos, el autor vuelve a referirse a la fecha y escribe: «Alude aqui Mossen Juan de Dueñas al desventurado D. Carlos, príncipe de Viana, todavía en su primera juventud, pues no pasaba de diez y seis años en 1437». Y algo más adelante volvía a referirse a la supuesta cronología del poema de Dueñas: «...aquel Rodrigo de Rebolledo, que en 1438 esperaba en Navarra, con Mossen Juan de Dueñas, la venida á España del Infante D. Enrique, para revolver de nuevo á Castilla». Insiste luego el autor en esa cronología al subrayar que «los capitanes que Juan de Dueñas menciona» eran «los más activos y temibles enemigos de D. Alvaro, como iban á mostrar en breve los suceson), en referencia a la guerra entre facciones que volvería a producirse al retornar el infante a Castilla: don Enrique, dispuesto a «sustituir en la privanza y en el poder al Condestable, tornaba á la Península Ibérica en 1439 y entrándose en Castilla con el esposo de Doña Blanca, daba extraordinario calor al levantamiento del Almirante D. Fadrique» (Amador de los Ríos 1872: $54-55$ y 63). 
Agustín Rubio Vela. Militares, cortesanos y poetas en el entorno de los infantes de Aragón (14391445): las Coplas de Juan de Dueñas al infante don Enrique

Casi un siglo después, al editar los poemas de Dueñas, Francisca Vendrell (1958: 152) también sostenía que las Coplas fueron escritas en Navarra durante una primera estancia del poeta castellano en aquel reino: «Allí, en su primera estancia, había hecho el elogio de Carlos de Viana, joven, y ensalzó a Blanca, que acababa de desposarse con el infante Enrique, heredero de Castilla». Como, a juicio de la autora, el sobrino no sería otro que don Carlos, y los desposorios entre el futuro Enrique IV de Castilla y la infanta Blanca de Navarra, hija de Juan y hermana de aquél, tuvieron lugar en 1437 — la boda se celebró tres años después_- Vendrell venía a coincidir en lo esencial con Amador de los Ríos en cuando a la ubicación espacio-temporal del poema.

Ahora bien, Carlos nació el 29 de mayo de 1421 (Desdevises du Dezert 1889: 107). ¿'Tiene sentido que en un poema escrito entre 1437 y 1439 se le califique de «ninno de tan poca hedad»? La cronología propuesta por José Amador de los Ríos primero y más adelante por Francisca Vendrell no se aviene con el texto de Dueñas, ya que el príncipe de Viana tendría entonces entre 16 y 18 años. Precisamente en 1439 contrajo matrimonio con Inés de Clèves. Tampoco los calificativos «fermosa criatura», «lindo syn conparaçion» $\mathrm{O}$ «graçioso» parecen adecuados para aquel joven de exquisita educación y extraordinaria cultura, que ya había dejado de ser un adolescente y estaba a punto de casarse. Carlos no era — no podía ser—aquel niño de poca edad.

\subsection{Benito Ruano.}

Consciente, tal vez, de la contradicción, el medievalista Benito Ruano propuso otra cronología para las Coplas: «Nos atreveríamos a fecharlas en 1428 - escribió—, por dos circunstancias». La primera: «por ser el año en que D. Enrique, a la vuelta de su peregrinación a Santiago de Compostela, fue invitado por su primo el rey de Castilla a dirigirse a la frontera andaluza para impedir la entrada, que por entonces se temía, de los moros», lo que explicaría el «guerrear a descreydos», según el autor, quien señala también — segunda circunstancia — que en dicha fecha Carlos de Viana «tendría apenas ocho años y se hallaría desde luego junto a su madre, Doña Blanca», quien, desde Navarra, había hecho llamamientos a su marido para que abandonase Castilla y «le pluguiese ir en su reyno, porque le cumplía mucho» (Benito Ruano 1964: 180-181). Don Juan, sus cortesanos y el poeta habían de estar en Navarra en 1428, cuando éste compuso las Coplas en las que daba cuenta a don Enrique de las bellas cualidades de su sobrino Carlos.

Ahora bien, un análisis de los acontecimientos de ese año obliga a poner en duda la interpretación. A comienzos de 1428, Juan y Enrique estaban en la corte de Juan II de Castilla, donde se vivían momentos de paz y concordia. El 6 de febrero, los infantes de Aragón, reconciliados entre sí tras años de fuerte enemistad, y ambos en buena relación con el monarca castellano, salían al encuentro de Álvaro de Luna en Turégano, donde el condestable, según escribe Zurita (XIII, XLV), entró «con tanto fausto y pompa como si hubiera alcanzado una gran victoria de sus enemigos». ${ }^{3} \mathrm{De}$

3 La Crónica de don Álvaro de Luna da cuenta de ello con estas palabras: «E salió el rey de Navarra, e el ynfante don 
Agustín Rubio Vela. Militares, cortesanos y poetas en el entorno de los infantes de Aragón (14391445): las Coplas de Juan de Dueñas al infante don Enrique

ahí el recelo de «algunos grandes del rreyno» ante la aparente armonía: observaban cómo «el rrey de Nauarra y ynfante don Enrrique tenían la mano en la gouernaçión del rreyno, y que todas las libranças se fazían por su auctoridad y mandado, lo qual se fazía por el crédito que el condestable [Álvaro de Luna] les daua en la voluntad del Rey, la qual él tenía muy enteramente». Son palabras de Lope Barrientos, quien, al igual que el cronista Carrillo de Huete, confirma que los infantes permanecieron junto al monarca castellano en los meses siguientes, primero en Segovia y luego en Valladolid (Carriazo 1946-b: 56-67; Carriazo 1946-a:17-29). En esta ciudad, con motivo del paso hacia Portugal de Leonor, hermana de los infantes, para celebrar bodas con Duarte, tanto ellos como Juan II organizaron grandes fiestas en los meses de la primavera, en las que don Enrique deslumbró con una exhibición caballeresca (Rico 1990: 178; Suárez Fernández 2005: 170 171 y 201-203).

Pero, como es sabido, la concordia, frágil, no iba a ser duradera. El deseo del rey de Castilla era que ambos hermanos, reconciliadospero no bien avenidos, partiesen de su reino: «la intención del Rey era que no estuviesen allí mas de quanto librasen sus negocios» (Rosell 1953: 445). Y lo consiguió de Juan de Navarra, quien el 6 de agosto, acabadas las celebraciones, se despidió del monarca de Castilla argumentando «que por algunas cosas le convenía yr a su rreyno de Navarra» (Carriazo 1946-b: 68). Enrique permaneció en tierras castellanas. Primero estuvo en Galicia, donde peregrinó a Santiago, tras lo cual, «hubo carta del Rey por la qual le embió mandar que no viniese por la Corte, mas que fuese derecho á la frontera de los Moros con cierta gente de armas, porquel Rey fue certificado que los Moros querian entrar por hacer daño en algunos lugares de la frontera; y el Infante púsolo así por obra» (Rosell 1953: 448). ${ }^{4}$ Consta que, con posterioridad a su actuación militar, recibió la visita de su cuñado, Juan II, quien «fué a Yepes, a ver a la ynfante doña Catalina, su hermana, que estaua allí, y a su marido el ynfante don Enrique» (Carriazo 1946-b: 68-69). El Halconero fecha este encuentro en diciembre de 1428, pocos días antes de la partida de Enrique hacia la Corona de Aragón: «E luego, miércoles veinte y nuebe días del mes, primero del ochauario de Navidad, partió el ynfante don Enrrique para el rrey de Aragón su hermano» (Carriazo 1946-a: $31-32) .^{5}$

Si, como sostuvo Benito Ruano, las Coplas de Dueñas se compusieron en 1428 en la corte de

Enrrique su hermano [...], e todos le fizieron muy alegre e graçioso resçebimiento [...] En esta guissa aconpañado e resçebido entró el Condestable en la corte, e quando llegó al Rey, fízole grand reverencia» (Carriazo 1940: 68). También la Crónica de Juan II: «Saliéronlo á rescebir el Rey de Navarra y el Infante Don Enrique, é todos los otros Grandes del Reyno que allí estaban. E así acompañado llegó á hacer reverencia al Rey, el qual le hizo muy alegre rescebimiento, é dende adelante tornó á la governacion como de primero» (Rosell 1953: 446).

4 Sáiz Serrano interpreta que «las desavenencias entre Juan, rey de Navarra, y Enrique, maestre de Santiago» fueron aprovechadas por Álvaro de Luna para obligar «al primero a regresar a Navarra y al segundo a partir hacia los dominios de la orden de Santiago en el sur con el pretexto de defender la frontera con Granada» (2008: 27).

5 No coincide esta fecha con la del 1 de febrero de 1429, día en que habría emprendido Enrique su camino hacia Aragón según Vicens Vives (2003: 67).

SCRIPTA, Revista internacional de literatura i cultura medieval i moderna, núm. 9 / juny 2017 / pp. 113-143 ISSN: 2340 - 4841 doi:10.7203/SCRIPTA.9.10214 
Agustín Rubio Vela. Militares, cortesanos y poetas en el entorno de los infantes de Aragón (14391445): las Coplas de Juan de Dueñas al infante don Enrique

Navarra, tendrían haberlo sido con posterioridad a la llegada al reino de Juan, que se despidió el 6 de agosto de su primo el monarca castellano. Así pues, Juan de Dueñas habría tenido que hacer la poética descripción del niño Carlos de Viana a su tío don Enrique entre el mes de agosto avanzado y diciembre, lo que, desde una perspectiva cronológica, choca con el deseo «de vos ver por el verano guerrear a descreydos» si, tal como lo interpreta el investigador, es una referencia a la expedición contra los moros de ese año. ¿Cómo hablar en futuro de una expedición estival cuando acababa o había acabado el verano de 1428? La referencia de las Coplas a la intervención fronteriza estival del infante Enrique no se aviene con la cronología propuesta por Benito Ruano.

Hay más circunstancias que la contradicen. En el año 1428, pese a su forzada reconciliación, perduraba la tensión entre los dos hermanos, fuertemente enemistados no mucho tiempo atrás. ${ }^{6}$ Da cuenta de ello el cronista de Juan II: «Dende á poco el Infante Don Enrique demandó licencia al Rey para ir á Santiago porque lo tenia prometido; de lo qual al Rey de Navarra no placía, é trabajaba con él porque lo no pusiese en obra, é no lo pudo acabar [...] E aunque el Rey de Navarra estaba en Medina, y él pasó por Toro, que esperaba de lo ver ante que pasase á su tierra, el Infante no dió lugar a ello, é pasóse sin detenimiento alguno; de lo qual se conosció que ya no estaban tanto concertados como solian. Y el Infante estaba muy quexoso del Rey de Navarra, aunque no lo mostraba, por la amistad que trataba con el condestable, sin gelo hacer saber. Y el Rey de Navarra asimesmo era quexoso del Infante porque sabia que trataban ya sus hechos con el Rey, é aun con el Condestable Don Alvaro de Luna sin le hacer saber cosa alguna. E algunos afirmaban quel Infante procuraba la partida del Rey de Navarra deste Reyno, ó hablaba con algunos secretamente que la procurasen» (Rosell 1953: 448). En las Coplas de Dueñas se percibe un intenso afecto entre Juan de Navarra y el infante Enrique, que en 1428, a juzgar por las líneas que acabamos de citar, extraídas de una crónica coetánea, aún no existía.

\subsection{Nancy Marino y Brian Dutton.}

Años después de la publicación del estudio de Benito Ruano, Nancy Marino (1985), desconocedora de ese trabajo, ${ }^{7}$ fechaba el poema en 1426 , con una simple y escueta justificación, a todas luces insuficiente: «En 1426 se formó un consejo para resolver algunos de los muchos conflictos entre

6 El 10 de octubre de 1425, don Enrique, preso en Castilla desde junio de 1422 por orden de Juan II, recobró la libertad gracias a la presión de Alfonso el Magnánimo, que quiso poner fin a la enemistad que enfrentó a sus hermanos Juan y Enrique. La concordia fraternal fue escenificada en 1426 en Tarazona, donde tuvo lugar el célebre abrazo entre los tres «infantes de Aragón» (Benito Ruano 1964: 164-165; Silió 1935: 105-106).

7 Lo que le hubiera evitado incurrir en algunas interpretaciones erróneas, como la de que el «guerrear a descreydos» sería la referencia a alguna batalla entre las facciones de la guerra civil castellana: «La batalla mencionada arriba podría ser una de las muchas luchas con Castilla durante los veinte años de guerra civil; sería difícil precisar de cuál se trata» (Marino 1985: 146). Es obvio que Dueñas aludía a las campañas militares estivales contra los musulmanes («descreydos») granadinos. 
Agustín Rubio Vela. Militares, cortesanos y poetas en el entorno de los infantes de Aragón (14391445): las Coplas de Juan de Dueñas al infante don Enrique

los reinos en cuestión» (Marino 1985: 146). Es ésta la fecha que encontramos en la influyente obra de Brian Dutton (1990-1991: I, 503), quien parece haber aceptado de manera implícita lo propuesto por la hispanista para las Coplas.

$\mathrm{El}$ argumento esgrimido para establecer esa cronología, además de insuficiente, es producto de una interpretación equivocada de una frase extraída de la Crónica de Juan II, según la cual el monarca, en 1426, «quiso haber consejo para ver de qué forma se podrian remediar las grandes costas que tenia, asi de mercedes, é raciones, é quitaciones y tierras, que eran tanto crescidas [...]; sobre lo qual bubo muy grandes altercaciones en su Consejo [...]» (Rosell 1953: 437). Evidentemente, el consejo reunido en 1426 era una institución, el consejo real de Castilla, convocado para abordar problemas internos, no «un consejo» que «se formó» con la finalidad de «resolver» conflictos entre los reinos peninsulares de Castilla, Aragón y Navarra, como interpretó la autora. Nada permite relacionar, en cualquier caso, la celebración de esta asamblea institucional con la composición de las Coplas, y ni siquiera con los infantes de Aragón. La inanidad del argumento es absoluta.

\section{El entorno de Juan de Navarra.}

Asunto clave para la comprensión del poema y el establecimiento de la cronología es la identificación de los hombres aludidos en él. Un problema sobre el que Amador de los Ríos pasó de largo, limitándose, como hemos visto, a calificarlos vagamente de «capitanes». Nancy Marino se refirió a ellos como un conjunto —una lista»— de individuos «que, junto a él [el poeta Juan de Dueñas], han decidido apoyar a don Enrique», incurriendo de nuevo en un error al interpretar los saludos al infante como una decisión de darle apoyo. Su identidad no parece haber interesado a la autora, que se limitó a escribir: «Algunos son llamados sólo por el apellido (Fajardo, Pacheco, Guevara, Rebolledo), lo que hace dificultosa su identificación. Otros son personas cuyos nombres se han perdido en la historia: Juan de Puelles, Fernando de Sandoval» (Marino 1985: 146).

Cuando veían la luz estas palabras, hacía más de dos décadas que había sido abordada la cuestión, con bastante meticulosidad, por Benito Ruano (1964: 180-183), cuya aportación ha sido el único intento serio de análisis acometido hasta ahora para el establecimiento de la fecha y contexto histórico de las Coplas. En las líneas que siguen, con esa aportación como valioso punto de partida, intentaremos aportar más luz.

\subsection{Rui Díaz de Mendoza.}

Entre las personas que enviaron saludos a don Enrique desde la corte de Juan de Navarra, Dueñas coloca en el primer lugar a «Ruy Dias el principal», cuya identificación con Rui Díaz de Mendoza, el 
Agustín Rubio Vela. Militares, cortesanos y poetas en el entorno de los infantes de Aragón (14391445): las Coplas de Juan de Dueñas al infante don Enrique

Calvo, no ofreció la menor duda a Benito Ruano. ${ }^{8}$ Todo indica que le asistía la razón. De su cercanía tanto al rey de Navarra como al gran consejero y privado de éste, el adelantado Diego Gómez de Sandoval, conde de Castro, dio testimonio otro poeta, Alfonso de Baena, en el «desir» que hizo «a Rruys Dias de Mendoça, el Calvo, pidiendole fauor para con el señor infante» (Azáceta 1967: 941942), donde se evocan los hechos de armas en que participó:

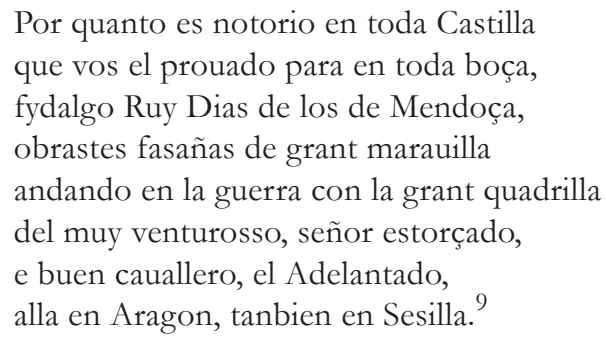

Ambos nobles, Gómez de Sandoval, adelantado de Castilla, y Rui Díaz de Mendoza, habían sido militares al servicio de Fernando de Trastámara, el padre de los infantes. Tras la batalla del Codolar (27 de febrero de 1412), que tuvo lugar en las proximidades de Sagunto durante el Interregno y que, como es bien sabido, fue una victoria decisiva de la facción que apoyaba la candidatura del infante castellano al trono de la Corona de Aragón sobre sus rivales urgelistas, partidarios de que fuese coronado Jaume d'Urgell (Rubio Vela 2003: 202, 214-215 y 224-225), Sandoval, artífice y uno de los grandes protagonistas de la victoria, envió a Díaz de Mendoza, entonces servidor suyo, a la corte de Castilla para que personalmente hiciera a Fernando el relato del combate y le entregase el pendón real de la ciudad de Valencia, tomado por él mismo: «E señor para que vuestra merçed sepa mejor la ordenança que se fizo enesta vatalla enbio ala vuestra merçed aRuy diaz de mendoça e ajuan carrillo mis criados que faran rrelaçion mas larga miente ala vuestra merçed como fue todo el fecho E [...] otrosy señor rruy diaz de mendoça tomo el pendon rreal de valençia el qual lieua ala vuestra merçed» (Garcia 1970).

Rui Díaz, camarero y «guarda mayor» del infante Juan, desde 1426 figura junto a él en Castilla, en lucha contra su gran enemigo, don Álvaro de Luna (Silió 1935: 111; Benito Ruano 1964: 182; Marino 1985: 146; Méndez Apénela 2004: 27). Algunos años más tarde, tras la batalla naval de Ponza, que tuvo lugar en aguas del Tirreno en 1435, ambos —el rey de Navarra y Rui Díaz- compartieron cautiverio en el castillo de Génova según los cronistas castellanos. Así dice la Crónica del Halconero: «El rrey de Navarra con todos los sobre dichos fueron llevados a Génoua, e puestos en el castillo con el apartados estos que se siguen: micer Antonio de la Águila, Ruy Días de Mendoça, los dos fijos del conde de Castro» (Carriazo 1946-a: 219). En la Refundición de la crónica del Halconero se lee también que acompañaron a don Juan en el cautiverio «miçer Antonio del Águila, e Rui Díaz de

$8 \mathrm{El}$ autor precisa que se trataba del apodado «el Calvo», no de un homónimo que fue mayordomo mayor del rey de Castilla (Benito Ruano 1964: 182).

9 El mismo poeta, en otro «desir» que hizo «a don Diego Gomes de Sandouar, adelantado mayor de Castilla», se refiere a éste como «capitan de grant quadrilla» (Azáceta 1967: 934-936). 
Agustín Rubio Vela. Militares, cortesanos y poetas en el entorno de los infantes de Aragón (14391445): las Coplas de Juan de Dueñas al infante don Enrique

Mendoça el Caluo, e el conde de Castro e sus dos fijos. Los quales fueron puestos en el castillo de Génoua» (Carriazo 1946-b: 195). ${ }^{10}$ Zurita recoge la noticia en sus Anales (XIV, XXVII): «Del reino de Castilla quedaron presos en la batalla don Juan de Sotomayor que fue maestre de Alcántara, el adelantado Diego Gómez de Sandoval y don Hernando y don Diego sus hijos, Ruy Díaz de Mendoza el Calvo, don Iñigo de Avalos y don Iñigo de Guevara, hijos del condestable don Ruy López de Avalos, Francisco de Villalpando y otros muchos caballeros de cuenta».

No debe pasar inadvertido el hecho de que, junto a Rui Díaz de Mendoza, entre los presos castellanos hubiera personas portadoras de dos ilustres apellidos que también aparece en las Coplas de Dueñas: Sandoval y Guevara.

\subsection{Fernando de Rojas Sandoval, Rodrigo de Rebolledo y Juan de Puelles.}

El mayor de los hijos del adelantado Diego Gómez de Sandoval, conde de Castro, también compañero de prisión de Rui Díaz, no es otro que el «Ferrando de Sandoval» que ocupa el tercer lugar en la relación de cortesanos de las Coplas de Dueñas. Primogénito del magnate castellano, de quien heredaría el título, Fernando de Rojas Sandoval fue, al igual que su padre, uno de los hombres más relevantes de la corte de Juan de Navarra. Benito Ruano se equivocó al creer que el «Ferrando de Sandoval» del poema no podía ser el hijo del conde de Castro porque éste «utilizaba sólo el apellido paterno, Gómez» (1964: 182-183). No es así. Se le citaba habitualmente como Fernando de Rojas. Así, en la Crónica del Halconero de Juan II: «...en la villa avía entrado don Fernando de Rojas, fijo del conde de Castro don Diego Gómez de Sandobal» (Carriazo 1946-a: 397). Y Palencia, en Gesta hispaniensia: «...cui praesidebat Fernandus de Roias primogenitus comitis Castri» (Tate y Lawrance 1998-1999: I, 11); según la Crónica anónima de Enrique IV de Castilla «...se fue a Gumiel de Mercado donde estava doña Juana Manrrique, muger de don Fernando de Rojas, conde de Castro, donde el prinçipe fue alegremente resçebido e servido» (Sánchez-Parra 1991: II, 285). Pero también con el de Fernando de Sandoval, con el que figura en el documento, fechado en Tarazona el 5 de julio de 1430, por el que el Juan de Navarra, que lo nombró mayordomo, dio poderes a quienes lo iban a representar en la firma del acuerdo de tregua con el rey de Castilla: «mossen Ferrando de Sandoval, mayordomo del dicho senyor rey de Navarra» (Gual Camarena 1951: 96). Con este nombre también es mencionado por dos dietaristas del siglo XV al informar de los castellanos que sufrieron prisión tras la batalla de Ponza. ${ }^{11}$

10 De la resonancia que tuvo este hecho da cuenta Pero Tafur, quien visitó el lugar al llegar a Génova: «Allí me mostraron la mala paga do estavan presos aquellos cavalleros que fueron presos con los reyes de Aragon é de Navarra» (Jiménez de la Espada 1995: 22).

11 El valenciano Melcior Miralles: «lo maestre de Alcàntera. Los Enigos, tres jermans, fills del conestable de Castella. Lo conte de Castro. Don Ferando de Castro. Royís Dies de Mendoça. Ferando d'Ávalos. Mossén Lope d'Angullo. Mossén Francesch de Vilapando. Mossén Reboledo [...] Mossén Alfonso Fajardo. [...] Mossén Rodrigo d'Angulo. Mossén Ferrando de Sandoval [...] Mossén Enyego de Gumera [sic, por Guivara]. Enyego d’Ávalos» (Rodrigo Lizondo 
Agustín Rubio Vela. Militares, cortesanos y poetas en el entorno de los infantes de Aragón (14391445): las Coplas de Juan de Dueñas al infante don Enrique

Amante de la poesía —fue autor de un poema de cancionero (Vendrell de Millás 1945: 45 y 291; Alonso 2006: 181) —, no resulta extraño que Juan de Dueñas, que militó tempranamente en el partido de los infantes (Salvador Miguel 1977: 77-84), incluyera a Fernando entre las personas que saludaban a Enrique. El afecto de Juan de Navarra hacia el conde de Castro y sus hijos era una evidencia. Una de las múltiples pruebas que hay de ello son las negociaciones entabladas con el rey de Castilla, con posterioridad a la derrota de Olmedo (1445), para llegar a un acuerdo de paz, en las que el de Navarra exigió de manera insistente y sistemática la devolución «al conde y condesa de Castro de todo lo que tenían en Castilla» (Zurita: XVII, XXVII).

Pero Juan de Navarra pretendía que, además de que fuesen devueltos los bienes confiscados «al conde de Castro y a los otros caballeros de su casa», restituyesen los suyos a otros de sus fieles, dos de los cuales nos interesa destacar aquí: «a don Rodrigo de Rebolledo [...] y a Juan de Puelles y por otros caballeros que eran de la casa del rey y del infante don Enrique». Son palabras de Zurita (XVII, XXVII), que insiste más adelante: «se debían restituir al conde de Castro y a los otros caballeros de su casa que eran Lope de Vega, don Rodrigo de Rebolledo, Juan de Puelles y Lope de Angulo» (XVII, XxxIII).

Rebolledo y Puelles son, no por casualidad, dos de los nombres que afloran en las Coplas de Dueñas. Militares castellanos ambos, y fieles servidores de Juan de Navarra en las guerras civiles de Castilla, el segundo es aludido en términos elogiosos en la Crónica de Juan II: «...habia en ella setenta de caballo, de hombres muy escogidos, criados del Rey de Navarra, el Capitan de los quales era muy esforzado caballero, llamado Mosen Juan de Puelles» (Rosell 1953: 651). Hay noticia de su participación en la batalla de Ponza gracias al marqués de Santillana, que en la célebre estrofa LXXIV de su Comedieta de Ponça (Kerkhof y Gómez Moreno 2003: 332), al referirse a los fieles del rey de Navarra que combatieron con él, escribió su apellido junto al de Sandoval, Mendoza, Fajardo y otros:

\footnotetext{
Allí se nombravan los de Sandoval, los de Avellaneda e Sotomayor;

Castro e Mendoça con saña mortal mostravan quién eran en la gran furor.

Fajardos e Angulos, pungidos de honor, buscavan las proas a grand diligençia;

Avalos e Puelles con toda femençia non menos fazían, pospuesto temor.
}

También luchó en la batalla naval Rodrigo de Rebolledo, protagonista de una acción que le haría merecedor de la gratitud eterna del futuro Juan II de Aragón: «Y fue cosa muy cierta y sabida

2011: 197). Y el catalán Jaume Safont: «lo mestra d’Elcàntera, lo comte de Castre ab dos fills; Roís Díez de Mandossa, mossèn Fferrando d'Àvelos, mossèn Enyago de Guinar [sic, por Guivar], qui aprés fonch comte d'Ariano, mossèn Lopis Avellaneda, mossèn Guterris de Sendoval, mossèn Llopis d'Angul ab dos germans [...], mossèn Rebolledo [...], mossèn Francesch de Vilapando [...] mossèn Fferrando de Sendovalı (Sans i Travé 1992: 34). En un par de documentos de los años 1457 y 1467 aparece como Fernando de Sandoval «alias de Rojas» (Olivera Serrano 2016: 406 y 835). Tardíamente, también lo cita así Blasco de Lanuza: «don Hernando de Sandoual, Conde de Castro, hijo del adelantado Gomez de Sandoual» (1622: 127). 
Agustín Rubio Vela. Militares, cortesanos y poetas en el entorno de los infantes de Aragón (14391445): las Coplas de Juan de Dueñas al infante don Enrique

que el rey de Navarra fuera muerto en la batalla si no se hallara a su lado un caballero de su casa, natural del reino de Castilla, de Castrojeriz, que desde su niñez le siguió y sirvió siempre, que fue muy valiente y señalado capitán y de los muy valerosos que hubo en sus tiempos y se llamó Rodrigo de Rebolledo». Zurita, autor de las líneas anteriores (XIV, XXVII), al referirse a los «muy principales señores que fueron prisioneros» en Ponza, escribió: «y Rodrigo de Rebolledo, que se rindió juntamente con el rey de Navarra». Su proximidad a don Juan es una evidencia de la que se hacen eco los cronistas: «Mosen Rebolledo, un Caballero de quien el Rey de Navarra mucho fiaba», se lee en la Crónica de Juan II (Rosell 1953: 554); «mosén Reuolledo, vn probado del rrey de Nabarra»; «Rodrigo de Robolledo, pribado del rrey de Nauarra», dice la Crónica del Halconero (Carriazo 1946-a: 287 y 399). Zurita, que lo califica de «caballero muy privado del rey de Navarra», puso en su boca estas elocuentes palabras: «iCómo queredes vos, señor, que yo yerre al rey de Navarra que me crió!» (XIV, LVIII; XV, XLI). ${ }^{12}$

Se puso de relieve esa absoluta fidelidad en 1446, después de la batalla de Olmedo, cuando fueron ocupadas por el rey de Castilla las villas que los infantes de Aragón poseían en su reino, salvo Atienza y Torija, tomadas, respectivamente, por Rodrigo de Rebolledo y por Juan de Puelles, que siguieron hostigando al monarca castellano desde ellas, según escribe Palencia en Gesta hispaniensia (Tate y Lawrance 1998-1999: I, 27). Y en la Crónica del Halconero: «e las dichas fortalezas de mano del rrey de Navarra; la vna en poder de mosén Revolledo, la otra en poder de mosén Juan de Puelles, según que primero las tenía» (Carriazo 1946-a: 476). Escribió Zurita al respecto: «el rey de Navarra [...] se apoderó de la villa y fortaleza de Torija y puso en ella con muy buena gente de guarnición un caballero que se decía Juan de Puelles; y en la villa y castillo de Atienza estaba con muy buenas compañías de gente de caballo Rodrigo de Rebolledo; y estos dos caballeros desde aquellas fortalezas corrían sus comarcas y hicieron muy grandes cabalgadas» (XV, XLI).

\section{3. «Los Fajardo y Gueuara»}

Mencionados por Dueñas en sexto lugar, los Fajardo eran Diego y Alonso, los hijos de Juan Fajardo, señor de Alhama, según Benito Ruano (1964: 182). El primero solía acompañar en la corte de Juan de Navarra al ya mencionado Díaz de Mendoza, tío suyo, según Méndez Apénela: «Ruy Díaz de Mendoza parece que tenía una especial inclinación hacia su sobrino Diego Fajardo, del que se hace acompañar en la corte del rey de Navarra». Señala el autor que acabamos de citar cómo el 9 de septiembre de 1432 «tío y sobrino son testigos de una acto regio en Tudela» (2004: 28). Un año antes, el 17 de agosto de 1431, se encontraban en Barcelona, donde consta que actuaron como testigos, juntamente con Rodrigo de Rebolledo, en la firma de un acuerdo entre Hug de Cardona

12 Autores modernos se han referido a esta privanza. Vicens Vives (2006: 76 y 140) alude a Rebolledo como el «fiel camarlengo» de Juan II y lo sitúa entre los «juanistas convencidos» al comenzar la crisis del reinado; Riquer lo presenta como un militar «de la confianza del infante don Juan» (1994: 61); y Sarasa como «el gran colaborador de don Juan» (2009: 26). Recientemente ha estudiado el linaje Hinojosa Montalvo (2015). 
Agustín Rubio Vela. Militares, cortesanos y poetas en el entorno de los infantes de Aragón (14391445): las Coplas de Juan de Dueñas al infante don Enrique

y Juan de Navarra. ${ }^{13}$ El otro hermano, «Mossén Alfonso Fajardo», según el dietario de Miralles fue preso tras la batalla de Ponza (Rodrigo Lizondo 2011: 197), en la que, de acuerdo con el verso de Santillana antes citado, actuaron «Fajardos e Angulos, pungidos de honor».

La aparición de «Guevara» en las Coplas de Dueñas apunta de nuevo, por un lado, al célebre combate naval, y, por otro, al entorno de los infantes de Aragón. Y obliga a referirse a Rui López Dávalos, condestable de Castilla, que fue principal caballero «de la opinión» del infante Enrique cuando comenzaron las desavencias entre éste y su hermano Juan en 1419. En 1423, al ser apresado don Enrique en Castilla, la infanta Catalina, su esposa, y el condestable Dávalos se refugiaron en la Corona de Aragón, donde este último murió en enero de $1428 .{ }^{14}$ Dos años antes se había producido la reconciliación entre Juan y Enrique. Siete después, en 1435, entre los castellanos que fueron apresados en Ponza figuraban «los Yñigos, fijos del condestable viejo don Rui López Dáualos» y «Fernando Dáualos, camarero del ynfante don Enrrique» (Carriazo 1946-b: 195).

Los primeros eran Íñigo de Guevara e Íñigo de Avalos, hijastro e hijo, respectivamente, de aquel notable exiliado. Servidores de los infantes de Aragón, hay noticia de su participación en la célebre batalla naval. Aparecen, con el apellido maltrecho por los copistas, en la lista de prisioneros que nos ha transmitido el dietarista Melcior Miralles: «Mossén Enyego de Gumera. Enyego d'Ávalos». Sin embargo, el mismo dietarista indicaba unas líneas antes que los Íñigos que cayeron prisioneros fueron tres: «Los Enigos, tres jermans, fills del conestable de Castella» (Rodrigo Lizondo 2011: 197). En otra relación, efectivamente, figuran seguidos tres miembros de la familia: «mossèn Ferrando d'Avelos, mossèn Enyago de Guinar, qui aprés fonch comte de Ariano; don Enyago de Guinar, qui aprés fonch comte camerlench» (Madurell Marimón 1963: 102).

El apellido Guevara sólo correspondía, stricto sensu, a Íñigo y Fernando de Guevara, hijastros de Rui López Dávalos, fruto del primer matrimonio de su mujer, Constanza de Tovar, con Pedro Guevara. Al quedar viuda, esta dama contrajo segundas nupcias con Rui López Dávalos, con el que tuvo

13 «Testes sunt qui fuerunt ac predicta presentes, Rodericus Díez de Mendoça, camerarius maior, Didacus Fajardo et Rodericus de Rebolledo, milites, domicelli [sic, por 'domus'] domini regis predicti» (Garcia-Oliver et alii, 2009-2011: I, 373).

14 Pedro de Escavias escribe que Catalina, «como supo la prisión del ynfante don Enrrique [...], fuese para Aragón, al rrey Don Alfonso, que era hermano del ynfante su marido, y casado con la rreyna doña María, hermana de la dicha ynfanta. Asimesmo se fue para allá don Rrui López de Dávalos, condestable de Castilla, con el mismo rreçelo. Y estando en Aragón, adoleció e falleçió» (Garcia 1972: 327; y Avalle-Arce 1972: 192). Pérez de Guzmán ubica el fallecimiento el 6 de enero en «Valencia del Çid», donde se encontraría su sepultura (Barrio Sánchez 1998: 90-91). Sin embargo, en la Crónica del Halconero leemos que el óbito se habría producido en Teruel: «En seys días del mes de henero, año del Señor de mill e quatroçientos e veinte y ocho años, día de los Reyes, murió Ruy López de Abalos, condestable que fue de Castilla, en Teruel, do estava el rrey don Alfonso de Aragón» (Carriazo 1946-a: 15). Es evidente el desacuerdo entre los historiadores en cuanto al lugar. Unos, siguiendo al Halconero, aluden a Teruel (Zurita: XIII, XLV; Vicens Vives 2003: 63); otros, tal vez la mayoría, a Valencia (Mota 1997: 59). En la Refundición del Halconero se afirma que Juan II de Castilla, estando en Segovia, «ovo nuevas don Ruy López Dáualos, que avía seydo condestable de Castilla, que avía salido desterrado con la ynfanta doña Catalina, muger del ynfante don Enrrique, que estaua en Valençia de Aragón, era muerto» (Carriazo 1946-b: 54). 
Agustín Rubio Vela. Militares, cortesanos y poetas en el entorno de los infantes de Aragón (14391445): las Coplas de Juan de Dueñas al infante don Enrique

dos vástagos varones: Íñigo y Alfonso Dávalos (Salvador Miguel 1977: 123-124; Tate y Lawrance 1998-99: I, 220, y II, 603; Croce 2007: 75). La duplicidad del nombre de pila, añadida a la confusión producida por los dos apellidos, Dávalos y Guevara, de los hermanos, ${ }^{15}$ nos lleva a sospechar que Fernando Dávalos, camarero del infante Enrique y prisionero en Ponza, y Fernando de Guevara eran la misma persona, citada en un caso con el apellido del padre y en otro con el del padrastro. ${ }^{16}$

Pero volvamos a las Coplas. En uno de sus versos aparecen «los Fajardo y Guevara», lo que podría entenderse, en el caso del segundo de los dos patronímicos, tanto en singular como en plural: «los Fajardo y [los] Guevara». Benito Ruano consideró que era alusivo a «los dos Iñigos de Guevara, hijos del condestable D. Ruy López Dávalos, uno de los cuales sería luego senescal en el reino de Nápoles, y su hermano, Iñigo Dávalos» (1964: 183). ${ }^{17}$ Desde una perspectiva documental, lo más verosímil y probable es que el «Guevara» de las Coplas sea Fernando de Guevara, a quien en 1440 localizamos en Toledo como testigo en un acto del infante don Enrique, juntamente con el poeta Juan de Dueñas: «Testigos que fueron presentes: mosén Iohan de Duennas e don Fernando de Gueuara e Gonçalo Martínez, freyre, capellán del sennor infante» (Ostos Salcedo 2008: 200-201).

De este interesante caballero, aficionado a los lances de armas y que, como poeta, «aparece en debates en verso con Juan de Dueñas» (Riquer 1965: 31-32), disponemos de un breve y excelente estudio biográfico realizado por Salvador Miguel, que hace observar esa relación personal con Dueñas, servidor asimismo de los infantes aragoneses, quien en una de sus composiciones se refirió a cierto viaje que Guevara hiciera a Portugal. Y escribe: «De la relación que facilitan las Crónicas se deduce que Fernando estaba al servicio del infante aragonés» (1977: 123-131). Efectivamente, los datos cronísticos indican que Fernando era hombre próximo al infante Enrique. En la Crónica de Juan II se le menciona junto a otros hombres de su casa en aquel año de 1440: «É otro dia hizo sala el Infante Don Enrique, é por mas honrar la fiesta, mandó hacer una justa en arnes real, de que fueron mantenedores Don Gabriel Manrique, Comendador mayor de Castilla, é Rodrigo Manrique, Comendador de Segura, é Don Fernando de Guevara, é Rodrigo Dávalos, é García de Padilla, y Lorenzo Dávalos, Caballeros de su casa» (Rosell 1953: 569). Lo mismo se lee en la Crónica del Halconero, en cuyas páginas se mezclan Dávalos y Guevaras: «Mantouo el comendador mayor

15 En la edición del dietario de Jaume Safont sólo figuran Fernando Dávalos e Íñigo de Guevara, también con grafía equivocada: «mossèn Fferrando d'Àvelos, mossèn Enyago de Guinar, qui aprés fonch comte d'Ariano» (Sans i Travé 1992: 34). Igualmente se refiere a dos Zurita (XIV, XXvII), que los llama «don Iñigo de Avalos y don Iñigo de Guevara, hijos del condestable don Ruy López de Avalos».

16 En 1444 intervino en representación del infante cuando fue acordado su matrimonio con Beatriz de Pimentel: «E luego desde allí partió Fernando Dávalos, Camarero del Infante Don Enrique, con poder del dicho Infante, para se tomar las manos con Doña Beatriz, hermana del Conde de Benavente» (Rosell 1953: 616).

17 Según Zurita (XIII, XL), Alfonso el Magnánimo «tuvo muy gran cuidado del remedio de los hijos del condestable [Ruy López de Avalos], y así puso en grandes estados en el reino a don Iñigo de Guevara y a don Iñigo de Avalos, sus hijos».

SCRIPTA, Revista internacional de literatura i cultura medieval i moderna, núm. 9 / juny 2017 / pp. 113-143 ISSN: 2340 - 4841 doi:10.7203/SCRIPTA.9.10214 
Agustín Rubio Vela. Militares, cortesanos y poetas en el entorno de los infantes de Aragón (14391445): las Coplas de Juan de Dueñas al infante don Enrique

de Castilla don Grauiel Manrrique, e Rodrigo Manrrique, comendador de Segura, e Fernando de Guebara, e Rodrigo de Avalos, e Garçía de Padilla, e Lorencio de Avalos. Estos eran de la casa del ynfante» (Carriazo 1946-a: 355). ${ }^{18}$

\subsection{Ramon de Sentmenat, Dueñas y la batalla naval de Ponza.}

La alusión a «Semenal», que Francisca Vendrell transcribió «Semenat», sin duda advirtiendo el error del copista, apunta al catalán Ramon de Sentmenat, que, tras la batalla de Ponza, figura entre «los presos de Cathalunya» (Vendrell de Millás 1958: 200; Benito Ruano 1964: 183). El valenciano Miralles, en la extensa relación de cautivos que proporcionó en las páginas de su Dietari, lo cita como «Mossén Ramon de Semenat» (Rodrigo Lizondo 2011: 194), y el catalán Safont como «Ramon de Sentmanat» (Sans i Travé 1992: 34). ${ }^{19}$ Así pues, al igual que seis de los personajes identificados en las Coplas de Dueñas - Rui Díaz de Mendoza, Rodrigo de Rebolledo, Fernando de Rojas Sandoval, Alonso Fajardo, Íñigo de Guevara e Íñigo Dávalos—-, Sentmenat combatió en Ponza.

Consta igualmente que el propio poeta, Juan de Dueñas, fue hecho preso en aguas del Tirreno tras el desastre: «pasó a Italia, acompañando a los infantes de Aragón, en la campaña que acabó tristemente en Ponza, en el año 1435. Hecho prisionero, fue encarcelado en la fortaleza de San Vicente, en Nápoles, como se ve por un epígrafe que se encuentra en el cancionero manuscrito 7819 de la Bibliothèque National de París, en el encabezamiento de la Nao de Amor, que dice: Fecha estando preso en la torre de San Vicente en Nápoles》 (Vendrell 1958: 151-152).

El análisis de las Coplas nos remite a un conjunto amplio de personas que participaron en la batalla naval y fueron apresadas tras la derrota, militares al servicio de los infantes de Aragón y de su partido, enemigo de la facción afecta a don Álvaro de Luna. Lo expresó así Vicens Vives: «en Ponza se rindió a los genoveses la flor y nata del partido aragonés», lo que fue una "gran contrariedad para tanto magnate que se había librado en Castilla de las zarpas del condestable» (2003: 86). ¿Fueron escritas las Coplas con posterioridad? Las biografías de las personas estudiadas en este apartado y los anteriores, aunque apuntan a ello, no permiten afirmarlo de manera concluyente. Pero hay un nombre clave, al que hasta ahora no nos hemos referido: «Pacheco».

18 Vidal González considera poco probable que Fernando de Guevara fuese el poeta de la «Pregunta a Gómez Manrrique de Gueuara», nombre éste que «plantea serios problemas de autoría» (2003: 241). Sin embargo, los datos cronísticos que acabamos de citar indican la proximidad de Fernando y de otros miembros de su familia a los Manrique, enemigos todos de Álvaro de Luna. Creemos oportuno recordar que «Ferrando de Sandoval» era el marido de Juana Manrique, hermana de Gómez Manrique.

19 Madurell Marimón leyó «Ramon de Sentmenat» (1963: 102).

SCRIPTA, Revista internacional de literatura i cultura medieval i moderna, núm. 9 / juny 2017 / pp. 113-143 ISSN: 2340 - 4841 doi:10.7203/SCRIPTA.9.10214 
Agustín Rubio Vela. Militares, cortesanos y poetas en el entorno de los infantes de Aragón (14391445): las Coplas de Juan de Dueñas al infante don Enrique

\section{Claves cronológicas.}

Posiblemente Benito Ruano, que no abordó el asunto de su identificación, descartó la posibilidad de que se tratara de Juan de Pacheco, el intrigante personaje que llegaría a ser marqués de Villena en 1445 gracias a la confianza que en él depositó el infante Enrique de Castilla, futuro Enrique IV, por un prejuicio: no tendría sentido que la persona que ha pasado a la historia como enemigo capital de los infantes de Aragón fuese la misma que envió saludos afectuosos a uno de ellos, por medio de Dueñas, desde la corte del otro. Sobre todo, teniendo en cuenta que el citado historiador, como el resto de investigadores del poema castellano, consideraba indudable — segundo prejuicio- que el sobrino niño era Carlos de Viana, hombre adulto cuando comenzó su carrera política el valido Pacheco.

A nuestro juicio, la identidad de ambos permite establecer el verdadero contexto cronológico de las Coplas. Conviene tener en cuenta dos aspectos. En primer lugar, que, salvo el futuro marqués de Villena, no se documenta ninguna persona llamada Pacheco entre las elites políticamente relevantes de Castilla, de Navarra y de la Corona de Aragón en la primera mitad del siglo XV. En segundo lugar, que en los versos de Dueñas no se indica quién era ese sobrino. Identificarlo con Carlos es una suposición, una idea preconcebida. Olvidan quienes lo afirman sin discusión que Juan de Navarra tuvo otros hijos varones nacidos fuera de matrimonio. A uno de ellos, de nombre también Juan, sobrino del infante Enrique, nos referiremos más adelante.

\section{1. La mención de Pacheco.}

Los cronistas de la época coinciden al presentar a Juan de Pacheco, joven amigo del príncipe Enrique de Castilla, como el artífice de la aproximación política fraguada entre él y sus primos, los infantes de Aragón, en 1440, que se tradujo en alianza contra don Álvaro de Luna, en frente común que duró cuatro años.

Hemos de remontarnos a septiembre de 1436, momento de la firma en Toledo de la paz que supuso el final definitivo del conflicto castellano-aragonés iniciado en 1429 (Gual Camarena 1951: 92). Gracias a ese acuerdo, los infantes de Aragón, tras casi una década en el exilio, pudieron volver a Castilla. El incesante conflicto interno entre facciones enemigas obligó a Juan II a buscar apoyo en sus primos, que regresaron de la Corona de Aragón. El 6 de abril de 1439, Juan de Navarra llegaba a Cuéllar. Las circunstancias permitían que llegara de facto con un papel de mediador, de «árbitro de las discordias» entre las facciones de don Álvaro de Luna y de los Manrique. Y, como escribiera un cronista coetáneo, con el beneplácito de su primo Juan II de Castilla: «con licencia del rey entró». De ahí que fuera recibido en Cuéllar con fiestas. Tres días después, cerca de allí, el rey de Navarra se veía con su hermano Enrique, ansioso por recuperar de facto el maestrazgo de Santiago, que Juan II le había prometido al invitarlo a venir a su reino (Vicens Vives 2003: 95-97). A partir de entonces, durante un lustro, los infantes fueron protagonistas principales — por segunda vez- en la política del reino castellano, donde siguieron teniendo frente a sí a don Álvaro de Luna. 
Agustín Rubio Vela. Militares, cortesanos y poetas en el entorno de los infantes de Aragón (14391445): las Coplas de Juan de Dueñas al infante don Enrique

Tras llegar a Castilla, Juan de Navarra no tardó en hacerse dueño de la situación. Primero mantuvo un cierto equilibrio entre las facciones políticas, pero pronto acabó en brazos de los magnates de la liga. El 30 de enero de 1440 firmaba con la reina de Castilla, María, su hermana, una alianza, en la que se encuadraron otros jerarcas de la nobleza, que lo vinculaba a la causa de Enrique, el príncipe de Asturias, alineado con los enemigos de don Álvaro, el valido de su padre. La boda del príncipe con Blanca, hija de Juan de Navarra, prevista por la paz de Toledo, se celebró el 15 de septiembre de 1440, con asistencia de los principales magnates del partido aragonés. Suegro ya del heredero, un triunfante don Juan estará presente en la corte de Castilla en los tiempos siguientes, siempre acompañado del fiel Diego Gómez de Sandoval (Vicens Vives 2003: 112-113; Silió 1935: 213; Benito Ruano 1952: 38; Olivera Serrano 2016: 17-18, 25-26, 29 y 32, docs. núm. 30, 46, 52 y 58).

Juan Pacheco, el doncel que había conseguido dominar la voluntad del príncipe Enrique, casi de su misma edad, y hacerse con el control de la casa, ${ }^{20}$ no fue ajeno a a esta circunstancia. Según las crónicas coetáneas, el favorito, movido por sus propios intereses, aprovechó su influencia sobre el príncipe para favorecer la buena relación entre éste y sus primos, los infantes de Aragón, frente a don Álvaro (Suárez Fernández 2002: 28-35). En las siguientes líneas, referidas al año 1440, el autor de la Crónica de Juan II relata así esa influencia y sus consecuencias: «El Príncipe Don Enrique tenia en su casa un Doncel, llamado Juan Pacheco [...] al qual el Príncipe tanto amaba, que ninguna cosa se hacia mas de quanto él mandaba; el qual queriendo poner al Rey [Juan II de Castilla] en necesidad, porque con aquella él se pudiese acrecentar, tuvo manera como el Príncipe se apartase de la voluntad del Rey, é siguiese al Rey de Navarra, el qual trabajó quel Príncipe se partiese de Valladolid é se fuese para la cibdad de Segovia, é desque allí estuvo, luego embiaron a él el Rey de Navarra y el Infante Don Enrique é los otros Caballeros de su parcialidad, é por intercesion suya el Principe se juntó con ellos, é firmó en la destruicion del Condestable» (Rosell 1953: 569). En el mismo sentido, y ubicándolo en la misma fecha, escribe el Halconero: «E tanto lugar dió el Príncipe a este Juan Pacheco, que por causa de alcançar estado desvió al Príncipe del camino de su padre, e llególo a la opinión del rrey de Navarra e ynfante; por lo qual tomaron mayor osadía de oponerse contra el Rey e contra el condestable» (Carriazo 1946-a: 356).

Se abrió así el lustro durante el cual brillaron los infantes de Aragón en Castilla, alcanzando su influencia política cotas máximas (Vicens Vives 2003: 98-124; Silió 1935: 199-229; Benito Ruano 1952: 38-39). Hasta que en 1444, cambiadas las circunstancias, la concordia acabó y se produjo la ruptura, propiciada por el mismo Pacheco que tiempo atrás había conseguido hábilmente aproximar a los primos (Suárez Fernández 2002: 47-52). Con admirable concisión, Garci Sánchez da cuenta del «rompimiento» en sus Anales: «En el mes de henero, febrero y marzo, año 1444, se juntaron en Avila el príncipe de Castilla y con él el condestable don Alvaro de Luna, y el Arzobispo de Toledo, y Pacheco. Y comaron voz diciendo que el rey estaba preso en Tordesillas, y que lo querían ir a deliberar, y facer

20 En marzo de 1440, Enrique de Castilla, lo hacía objeto de una importante merced: Juan Pacheco recibía de manos del príncipe varios lugares de los que éste era propietario: Monasterio, Campillo y Las Pozas (Olivera Serrano 2016: 31, doc. núm. 56). 
Agustín Rubio Vela. Militares, cortesanos y poetas en el entorno de los infantes de Aragón (14391445): las Coplas de Juan de Dueñas al infante don Enrique

otras cosas contra el de Navarra y contra los otros cavalleros de su opinión» (Carriazo Arroquia 1953: 34). El trueque de alianzas desembocaría al año siguiente en el enfrentamiento bélico definitivo entre los infantes de Aragón y el monarca de Castilla —ahora con el primogénito y don Álvaro a su lado-, que acabó con la derrota de aquéllos en Olmedo (19 de diciembre de 1445). Consecuencias de la batalla fueron la muerte del infante Enrique, la marcha definitiva a la Corona de Aragón de Juan de Navarra y el exilio de los nobles más significados de su facción.

Así pues, Juan de Pacheco, el personaje que ha pasado a la historia como uno de los grandes enemigos de los infantes de Aragón, fue favorable a éstos durante un tiempo, hasta el punto de ser presentado por los cronistas como el hombre que favoreció su alianza con el príncipe heredero de Castilla. Las Coplas de Dueñas pudieron haber sido escritas en Castilla entre los años 1440 y 1443, cuando «Pacheco», citado en uno de sus versos, intervenía en la vida política del reino en armonía con Juan y Enrique - fraternalmente unidos, ahora sí-, y comenzó su ascenso fulgurante en la corte, premiado en 1445 con el título de marqués. Desde la perspectiva cronológica que aquí nos interesa, resultan bien elocuentes las palabras del cronista acerca del fruto de sus habilidades y ambiciones: «sacó e alcançó tanto, que en spacio de seis años, dando cada año vna vuelta, llegó a ser marqués e señor del marquesado de Villena» (Carriazo 1946-a: 342 y 467). Nada tiene de extraño, por tanto, que quien en 1445 llegó a ser marqués de Villena y gran enemigo de los infantes de Aragón, fuese la misma persona que el Pacheco que poco tiempo antes enviaba saludos a don Enrique: el que propició en 1440 la alianza política que él mismo contribuyó a desbaratar en 1444, inicio del desencuentro que condujo al «rompimiento» definitivo. Este año podría ser, a nuestro juicio, terminus ante quem del poema, y 1439 el post quem.

\subsection{El sobrino niño.}

La cronología propuesta entra en contradicción, obviamente, con algo que hasta ahora ha sido considerado evidencia indiscutible: el sobrino elogiado por Dueñas era Carlos de Viana y la corte de Navarra - donde se encontraría don Juan y sus cortesanos - el lugar en que compuso las Coplas. Pero estamos ante una idea preconcebida, no ante una obviedad. No se ha tenido en cuenta la existencia de otro hijo de Juan de Navarra, niño que, precisamente, podría tener entre tres y seis años hacia 1440-1443. Veámoslo.

Bajo el epígrafe «Matrimonio de don Juan de Aragón, hijo del rey de Navarra, con hija del déspoto», ubicado en el año 1456, Zurita se refirió en sus Anales (XVI, XXXVII) a ese otro hijo no legítimo de Juan II, que con el paso del tiempo llegaría a ser arzobispo de Zaragoza, en estos términos: «Por este tiempo envió a Galcerán de Torrellas comendador de Bayoles de la orden de San Juan de Jerusalén a Demetrio Paleólogo déspoto de la Morea, con el cual se había tratado de concertar matrimonio de don Enrique hijo del infante don Enrique sobrino del rey con hija del déspoto; pero después, visto que don Juan de Aragón hijo del rey de Navarra y de una dueña de noble linaje de 
Agustín Rubio Vela. Militares, cortesanos y poetas en el entorno de los infantes de Aragón (14391445): las Coplas de Juan de Dueñas al infante don Enrique

los de Avellaneda, era de más edad y tenía diez y ocho años y estaba en la corte del rey, y el hijo del infante no tenía sino ocho años y estaba absente, se trató que el matrimonio de don Juan de Aragón se efectuase». Si en 1456 este hijo de Juan de Navarra tenía 18 años según la información de Zurita, debió nacer hacia 1438, lo que concuerda con otro dato proporcionado por Rius Serra (1927: 2930), según el cual a fines de junio del 58 el vástago tendría la edad 19 años. ${ }^{21}$

Volvamos a las Coplas dedicadas al infante Enrique, viudo sin hijos de la infanta Catalina desde 1439 — en 1444 casó en segundas nupcias con Beatriz de Pimentel—, en las que Juan de Dueñas expresaba dos deseos: que Dios le hiciera merced de concederle un vástago «atal qual vuestra merçed desea», adornado de la misma hermosura y gracia que las que el poeta, cortesano de Juan de Navarra, veía en el hijo de éste, sobrino niño del infante. Así pues, no existe contradicción entre la cronología propuesta y la edad del elogiado sobrino, a quien el padre procuraría un estatus futuro acorde con su rango, como tampoco se contradice con la mención de Pacheco. Por otro lado, un análisis de acontecimientos y personas relacionados con los infantes por aquellos años triunfales en Castilla — también crepusculares — apunta en esa misma dirección, como vamos a ver.

\section{Entorno y movimientos de los infantes.}

El periodo comprendido entre 1439, año de la llegada a Castilla de los infantes de Aragón, y 1444, el de su partida, previa a la derrota de Olmedo, fue para ellos un tiempo de esplendor. Fraternal y políticamente unidos, Juan se estableció en la corte, junto al rey, mientras que Enrique lo hizo en Toledo, cuyo «apoderamiento» fue uno de sus más tempranos y resonantes logros del infante. Ello explica sus largas ausencias de la corte y casa de su hermano, así como sus frecuentes viajes desde aquella ciudad para encontrarse con él, a lo largo de los años 1440, 1441 y 1442, de los que se hace eco la Crónica de Juan II. ${ }^{22}$ En el siguiente, 1443, partió desde Toledo para emprender operaciones militares en Andalucía: en enero de 1444 estaba de Córdoba, desde donde salió para Sevilla —en

21 Confuso en este sentido resulta Solano Costa $(1970: 7,11,12)$, que no tiene en cuenta la noticia de Zurita. Considera que el año de su nacimiento «pudo ser 1439 ó 1440» y que en 1458 «tenía [...] a lo sumo, diecinueve años», lo que no le impide afirmar que el 29 de junio de 1460 «contaba diecinueve o veinte años».

22 Así, en 1440: «lo qual se embió á decir al Rey de Navarra, quel Infante era ido á Toledo»; «la derramasen el Rey de Navarra, y el Infante su hermano, que estaba en Toledo»; «É como á este tiempo el Infante Don Enrique estuviese en Toledo...»; «debia ir contra el Infante Don Enrique que estaba en Toledo». En 1441: «habia acogido al Infante Don Enrique en la dicha cibdad [de Toledo]»; «fuesen á Toledo donde estaba el Infante Don Enrique»; «acordaron que el Infante se volviese á Toledo para la tener apoderada como solia»; «Despues que el Infante, estando en Toledo, supo...»; «fuéronse á juntar con el Infante, que salió á ellos á Camarena, aldea de Toledo»; «e que el Infante se volviese á Toledo; lo qual así se hizo, que luego todos se partieron desde Real, é se volvió el Infante para Toledo». En 1442: «En este tiempo, estando el Infante Don Enrique en Toledo...»; «E de allí el Rey embió mandar al Infante Don Enrique que estaba en Toledo...»; «En el año del Nascimiento de Nuestro Redemptor de mil y quatrocientos y quarenta y tres años, el Rey de Castilla tuvo la Navidad [navidad de 1442] en Toledo, y con él la Reyna su muger, y el Rey de Navarra, y el Infante Don Enrique...» (Rosell 1953: 563, 564, 567, 570, 577, 578, 579, 609, 610 y 611). 
Agustín Rubio Vela. Militares, cortesanos y poetas en el entorno de los infantes de Aragón (14391445): las Coplas de Juan de Dueñas al infante don Enrique

Écija se encontraba el día 28-, que trató infructuosamente de hacer suya (Cabrera 2001: 700-701 y 717; Olivera Serrano 2016: 35, doc. núm. 72).

Siendo esto así, se comprende que en las Coplas de Juan de Dueñas — que también compuso un decir «de la valía del rey nuestro sennor antes que el Infante entrase en Toledo», y un poema "sobre la sospecha que tenía dél quando el Infante entró en Toledo» (Benito Ruano 1964: 184-187)—, desde la corte y casa de su hermano se enviaran saludos al infante ausente, dirigidos, bien a Toledo, bien a Andalucía. No es posible precisar, con los datos de que disponemos, en qué fecha concreta. En rigor, sólo puede hablarse del contexto histórico, de la circunstancia de los años que van desde 1440 hasta 1443.

Por esas fechas, en el entorno de los infantes se detecta la presencia de algunos de los citados en las Coplas, lo que parece confirmar la cronología propuesta. En 1440, «en la dicha çibdat de Toledo, postrimero día del dicho mes de junio, anno susodicho, en la posada del dicho sennor ynfante maestre», al ser registrada la entrega de unas cartas de éste por el notario del capítulo de la orden de Santiago, figuran como testigos «mosén Iohan de Duennas e don Fernando de Gueuara» (Ostos Salcedo 2008: 200-201). Y este último, en octubre del mismo año, participaba en Valladolid en unas justas con otros caballeros de la casa del infante (Rosell 1953: 569).

Iguamente hay constancia de que Fernando de Rojas Sandoval participaba en el conflicto castellano en 1441, obviamente en las filas de Juan de Navarra. Palencia, en la Gesta hispaniensia, lo sitúa en Medina del Campo: «pars munitior Metinae, cui praesidebat Fernandus de Roias primogenitus comitis Castri» (Tate y Lawrance 1998-1999: I, 11). Antes de que el rey de Castilla llegara a esa localidad, Rojas entró «en la Mota de la dicha villa con sesenta hombres de armas», siendo poco después obligado a entregarla al monarca por su padre, que le envió una carta de requerimiento (Rosell 1953: 580; Carriazo 1946-a: 397-398). Ocurrió esto en mayo del citado año, y «con ciertas condiciones que se hicieron con don Fernando, hijo del conde de Castro, que ende estaba», según escribe Garci Sánchez, en cuyos Anales reaparece «don Fernando de Roxas» en junio del siguiente año de 1443, en las proximidades de Castrojeriz, intentando apresar al conde de Haro, quien actuaba «contra el rey de Navarra» (Carriazo Arroquia 1953: 31-32). En 1444 dice Pedro de Escavias que sufrió un descalabro: «acaeçió que Garçía de Ferrera venía con çien lanças a juntarse con el rrey de Navarra. Y como él supo que venía enbió a Fernán López de Saldaña y a don Fernando de Rrojas, con dos batallas, a los rrezibir y pasar en salvo [...] Y don Fernando de Rrojas, fijo del Conde de Castro, y Fernán López de Saldaña fueron desbaratados, y Garçía de Ferrera fue preso y destroçado» (Garcia 1972: 339; y Avalle-Arce 1972: 203-204).

Este mismo cronista da una noticia de otro de los citados, Juan de Puelles, combatiendo en 1444 en favor de Juan de Navarra: «E como llegó a Peñafiel, luego se le dio la fortaleza, que la tenía mosén Juan de Puelles y otros criados del rrey, por tratos, y luego que se la entregaron, mandóla derribar» (Garcia 1972: 340; y Avalle-Arce 1972: 204). Más prolijo es el relato de la Crónica de Juan II, que indica cómo ese año, en Peñafiel, el monarca castellano «asentó su Real, y cercó la villa á diez y 
Agustín Rubio Vela. Militares, cortesanos y poetas en el entorno de los infantes de Aragón (14391445): las Coplas de Juan de Dueñas al infante don Enrique

ocho dias de Julio [...] E mandó luego hacer su proceso contra Mosen Juan de Puelles, al qual el Rey de Navarra habia dexado cargo así de la villa como de la fortaleza, é contra todos los que dentro estaban, é contínuamente se hacian los pregones; é así estuvo el Real hasta diez y seis dias del mes de Agosto de este dicho año, quel Rey mandó combatir la villa por seis partes, é duró el combate por espacio de tres horas, é al fin entróse por fuerza, é fué metida á sacomano, é hízose en ella gran daño; é aunque el Rey lo quisiera estorvar no se pudo menos hacer. Mosen Juan Puelles desque vido la villa entrada, é que no la podia defender, acogióse á la fortaleza; é túvole el Rey cercado algunos días, pero al fin hizo su partido, que entregó la fortaleza al Rey» (Rosell 1953: 623-624).

Rui Díaz de Mendoza está asimismo documentado por entonces como uno de los militares al servicio de Juan de Navarra. El 29 de junio de 1439, según el Halconero, «envió el rrey de Navarra a Ruy Díaz el Caluo a Peñafiel, villa suya, con fasta quinientos de a cavallo, para que tobiese la villa para seruicio del Rey don Johan de Castilla» (Carriazo 1946-a: 293). Es interesante, desde el punto de vista cronológico, otro dato: en 1444 Rui Díaz cayó enfermo y Juan de Navarra se desplazó para visitarlo a la localidad de Aynzón, de la que era señora la mujer del fiel vasallo. Tres años después fallecía, y en el testamento instituyó heredero a su sobrino Diego Fajardo, al que legó la baronía de Benidorm. También sabemos que este último fue nombrado por Juan de Navarra para ejercer en su nombre la administración del marquesado de Villena, cuyo gobierno desempeñó al menos hasta septiembre de 1444, según Méndez Apénela, quien subraya de Fajardo «la fidelidad a su rey Juan de Navarra y por extensión a su hermano Enrique, el maestre de Santiago» (2004: 27, 29-30 y 33-34).

No sólo de Diego. También el segundo de «los Fajardo», su hermano Alonso siguió siendo afecto de los infantes de Aragón cuando periclitaba su poder en Castilla, según un dato del cronista Pedro de Escavias al que ya se ha aludido: en 1444, el infante Enrique, perseguido por el príncipe Enrique y por Álvaro de Luna, «tomó su camino para Lorca, do le acogió Alonso Fajardo que la tenia», gracias a lo cual evitó caer en poder de sus dos poderosos enemigos (Garcia 1972: 340; y AvalleArce 1972: 204). La Crónica de Juan II es más explícita cuando, en referencia al episodio y al infante, afirma: «Alonso Faxardo, alcayde de Lorca, que la tenia contra voluntad del Rey [de Castilla], le escribió que se viniese allí a Lorca, y que le acogeria allí en la villa, é le entregaria la fortaleza; lo qual el Infante luego hizo habiendo aquel por el mejor remedio que podia tomar. E como llegó a Lorca, Alonso Faxardo le entregó las llaves de la villa é de la fortaleza» (Rosell 1953: 624).

\section{Dos personajes enigmáticos.}

Dos apellidos enigmáticos aparecen en las Coplas: «Martel» y «Casteluy». Su identificación obliga a entrar en el terreno de las hipótesis con más cautela que en los casos anteriores, dada la carencia absoluta de datos aportados al respecto por los estudiosos. Por otro lado, las crónicas castellanas no constituyen una ayuda, al estar ausentes de sus páginas ambos nombres, que evocan la onomástica catalana, como debió de intuir Benito Ruano al escribir: «De Martell (sic) y de Castellví no hemos 
Agustín Rubio Vela. Militares, cortesanos y poetas en el entorno de los infantes de Aragón (14391445): las Coplas de Juan de Dueñas al infante don Enrique

conseguido una mayor identificación» (1964: 183). De ahí la necesidad de trasladarnos a un ámbito distinto, catalanoparlante, pero vinculado a Juan de Navarra, en cuya casa sitúa Dueñas a ambos personajes: el reino de Valencia.

\section{1. «Casteluy».}

«Casteluy» constituye, sin duda, una referencia a alguien de apellido Castellví, lo que nos ha llevado a un linaje valenciano, portador del patronímico, conocido y próximo a los infantes de Aragón en los años previos a su última etapa en Castilla. Efectivamente, los Castellví, notable y extensa familia de la pequeña nobleza de Valencia, no fue ajena a ellos. En 1430, Juan de Navarra, como lugarteniente general, escribió a su hermano Enrique, a la sazón en Valencia, para que mediara en la guerra particular que enfrentaba a Galceran de Castellví y los suyos con otro caballero, Bernat Joan, señor de Tous (López Rodríguez 2005: 204-207), y que tres años después proseguía, con gran preocupación del gobierno de la capital del reino. ${ }^{23}$ La noticia sugiere la existencia de una relación personal entre los protagonistas del «debat» y el infante, que no tenía cargo político alguno en el reino de Valencia: sólo gozando de la confianza de ambas partes se explica una propuesta de mediación destinada a conseguir el cese de acciones hostiles.

Más significativo es el contenido de las actas de las cortes valencianas celebradas en los años inmediatamente anteriores a la llegada a Castilla -1439— de los infantes de Aragón. Juan de Navarra, en calidad de lugarteniente general de su hermano, hizo la convocatoria el 15 de diciembre de 1436 y durante los dos años siguientes presidió las sesiones, celebradas en la catedral: «in dicta ecclesia cathedrali civitatis Valentie, dicto domino rege Navarre locumtenenti generali prefato personaliter residente, sedente ut moris est in trono regali». ${ }^{24}$ En enero de 1438 hacía acto de presencia en la asamblea «inclitus infans Enricus, magister ordinis sancti Iacobi de Spata et dominus civitatis Sugurbii», que asistió a las sesiones de los días 7 de enero, 12 de febrero y 28 de abril de ese año. En esta última tomó la palabra para presentar un escrito, en nombre del brazo militar, en el que se pedía que la oferta económica al monarca fuese gestionada por él mismo y el conde de Castro, junto con otras trece personas, una de las cuales era «mossén Johan de Castellví». ${ }^{25}$ En la sesión del 13 de mayo, el infante Enrique encabezaba la lista de asistentes del brazo militar, en la que también

23 El 4 de noviembre de1433, los ediles de Valencia, «attenents esser çert debat entre los honorables mossén Bernat Johan e mossén Galceran de Castellví e altres, e volents entendre en lo benavenir de aquells e pacificar-los [...] provehiren [...] que a l'honorable mossén Bernat Johan fossen trameses per missatgers, lla on fos, cuytadament, los honorables mossén Jacme Romeu, cavaller, e micer Guillem d'Alpicat, doctor en leys, jurats, per parlar ab aquell dels dits affers» (Archivo Municipal de Valencia [AMV], Manuals de Consells 30, f. 115v).

24 AMV, Procesos de Cortes yy-15, ff. 1r y 124v. Comenzaron el 20 de febrero de 1437 y el 20 de mayo de 1438 “foren licenciades e finides" (id., Claveria Comuna J-57, ff. 13v-14r).

25 AMV, Procesos de cortes yy-15, ff. 231v-232r; y Garcia-Oliver et alii 2009-2011: II, 697-698.

SCRIPTA, Revista internacional de literatura i cultura medieval i moderna, núm. 9 / juny 2017 / pp. 113-143 ISSN: 2340 - 4841 doi:10.7203/SCRIPTA.9.10214 
Agustín Rubio Vela. Militares, cortesanos y poetas en el entorno de los infantes de Aragón (14391445): las Coplas de Juan de Dueñas al infante don Enrique

se mencionaban «Iohannes de Castellví» y «Petrus de Castellví». ${ }^{26}$

La activa y continuada participación de miembros de la familia Castellví en esas cortes presididas por Juan de Navarra es un hecho del que dan cuenta las actas abundantemente. Valgan estas muestras: el 20 de febrero de 1437, se registran entre los caballeros «Iohannes de Castellví, Petrus de Castellví, Anthonius de Castellví, Galcerandus de Castellví», y entre los donceles «Ludovicus de Castellví, Iohannes de Castellví». ${ }^{27} \mathrm{Al}$ día siguiente, en la relación de militi estaban «Iohannes de Castellví, Petrus de Castellví, Anthonius de Castellví, Ludovicus de Castellví», y entre los domicelli «Ludovicus de Castellví, Iohannes de Castellví». ${ }^{28}$ El 1 de junio asistían «Iohannes de Castellví [...], Galcerandus de Castellví [...], Anthonius de Castellví [...], Petrus de Castellví, Ludovicus de Castellví [...] Iohannes de Castellví, Iohanot de Castellví». El primero de ellos tuvo un cierto protagonismo, ya que presentó, en nombre de una parte del brazo militar, un cuaderno de grenges: «Et ilico surrexit Iohannes de Castellví, miles, et nomine ac pro parte ut dixit nonnullorum de brachio militari dicti regni...» Entre los firmantes del documento estaban «mossén Johan de Castellví, mossén Anthoni de Castellví, mossén Pere de Castellví, mossén Galceran de Castellví, En Loís de Castellví, frare Loís de Castellví, per si e com a procurador d'En Francesch de Castellví, Johanot de Castellví, fill de mossén Galceran, Johanot de Castellví, fill de mossén Johan». ${ }^{29}$

No menos significativo es este otro dato: un Lluís de Castellví, hijo de Galceran de Castellví, fue nombrado caballero santiaguista por el infante Enrique, maestre de la orden. Efectivamente, poco después de la derrota de Olmedo, el 19 de diciembre de 1445, recientemente fallecido su hermano, Juan de Navarra juraba con solemnidad en Valencia el cargo de lugarteniente general del reino - por segunda vez, ya que lo había ejercido con anterioridad - ante las cortes. Entre los miembros del estamento militar allí presentes se encontraba «Ludovicus de Castellví, ordinis militie Beati Iacobi de Spata». ${ }^{30}$ Ocupaba un lugar entre los milites, no entre los clérigos, lo que indica que era caballero laico, no religioso profeso, obviamente por decisión del desaparecido maestre, que solía gratificar con distinciones y cargos en en la orden a sus servidores. ${ }^{31}$ Consta que este Lluís de Castellví era entonces un hombre joven. Había contraído matrimonio en $1442 .{ }^{32}$ Y sabemos que, tanto él como

26 AMV, Procesos de cortes yy-15, ff. $259 \mathrm{v}-260 \mathrm{r}$.

27 AMV, Procesos de cortes yy-15, f. 42r-v.

28 AMV, Procesos de cortes yy-15, ff. 49v-50r.

29 AMV, Procesos de cortes yy-15, ff. 124v, 125v, 127v y 129r.

30 AMV, Procesos de cortes yy-17, f. 310r.

31 Tal es el caso de Lope de Estúñiga, «un poeta lligat amb els infants d’Aragó i especialment amb l’infant Enric, el qual l'elevà en 1440 a trece de l'orde de Sant Jaume» (Torró 2009: 239).

32 En 1446-47 fue cancelado un censo municipal adquirido hacía más de tres décadas por mossén Pere de Castellví y que, tras haber pasado por herencia a varios miembros de la familia, llegó a manos de la madre de nuestro Lluís: 
Agustín Rubio Vela. Militares, cortesanos y poetas en el entorno de los infantes de Aragón (14391445): las Coplas de Juan de Dueñas al infante don Enrique

su mujer, Isabel Suau, vivían aún a comienzos de 1485, pues en enero, bajo la anotación «De $\mathrm{Na}$ Ysabell Suau, muller de mossén Loís de Castellví», ante el notario Jaume Ximeno, se redactaba un documento en el que se puede leer: «...recognosco vobis, nobili et magnifice Ysabelli Suau, uxori nobilis et magnifici Ludovici de Castellví, militis ordinis et militie Sancti Iacobi d'Espasia, habitatori dicte civitatis.... ${ }^{33}$

Es posible que fuera él, el caballero santiaguista valenciano mossén Lluís de Castellví, de familia afecta a los infantes de Aragón, el enigmático «Casteluy» de las Coplas de Dueñas, lo que significaría que por los años 1440-1443, siendo muy joven, estuvo en Castilla al servicio de Juan de Navarra.

\section{2. «Martel».}

«Martel» es el otro misterioso nombre mencionado en las Coplas. En este caso es preciso subrayar que en el entorno de los infantes de Aragón no aparece nadie con ese apellido. Su inexistencia es total, tanto en las crónicas como en la documentación, lo cual nos lleva a pensar en la posibilidad de un error de escritura producido en algún momento de la transmisión textual del poema de Dueñas. Cabe señalar al respecto que la única copia llegada hasta nosotros contiene no pocos fallos, algunos de los cuales indican que el copista —uno de los copistas al menos - era persona poco familiarizada con la onomástica catalana. Lo hemos comprobado anteriormente en el caso del vocablo «semenal», sin duda una mala lectura de «semenat», término con que debió ser transcrito el apellido catalán Sentmenat, que acabó en el casi irreconocible «semenal». Por razones similares, «martel» podría ser producto de una torpe lectura del patronímico «marturel», escrito con la típica abreviatura en forma de bucle — que obliga a leer «ur», o bien «or»— tras la letra «t»: «mart[ur] el». ${ }^{34}$

«la honorable dona $\mathrm{Na}$ Elionor de Castellví, mare sua, muller quondam de l'honorable mossén Galceran de Castellví, cavaller, axí com a hereva del dit son marit». El 3 de diciembre de 1442, Elionor lo traspasó a su hijo, «l'honorable mossén Luís de Castellví, cavaller, habitador de la dita ciutat, de l'orde de Sant Jacme de la Spasa», como parte de los cincuenta mil sueldos «a ell, en contemplació de son matrimoni promessos e donats» (AMV, Quitament de censals W-4, ff. 221r-222r). El 24 de abril de 1447, ante el notario Jaume Beneyto, se realizaba el quitament. «ego, Ludovicus de Castellví, miles ordinis beati Iacobi de Spata, habitator Valentie» reconocía haber recibido 7.500 sueldos pagados en 1412 por el caballero Pere de Castellví por el censo del que su madre fue última propietaria hasta que se lo transfirió a él el 3 de diciembre de 1442, con ocasión de su matrimonio: «dompna Elionor, mater mea, emptrix, nomine suo proprio et ut heres preffata, vendidit et alienavit, inter alia, dictos quingentos solidos censuales, cum omnibus iuribus suis, mihi et meis, in pacca et solutionem illorum quinquagenti trium millia solidos per eam dictis nominibus mihi contemplatione mei matrimonii» (id., Protocols, Jaume Beneyto, r-11, s. fol.).

33 AMV, Protocols, Jaume Ximeno t-17, s. fol. (1485, enero, 18). El 27 de enero del mismo año, en otra operación censal del caballero Joan Tolsà de Ripoll: «Item ex alia parte [... ] nobili et magnifice Ysabelli Suau, uxori nobilis et magnifici Ludovici de Castellví, militis ordinis et militie Sancti Iacobi d'Espata» (ibid., s. fol.). Todo apunta a que era la dama a la que poco después, tras haber enviudado en 1489, le fue dedicado «un anònim Pròleg d'una no poc devota adoració de Jesús, redemptor nostre, crucificat, endreçada a la senyora molt virtuosa dona Isabel de Castellví, viuda, datable a les darreries del XV, que s'ha d'afegir al catàleg de textos artitzats de l'època» (Ferrando 1999: 134).

34 El cierre de la o átona en la pronunciación de «Martorell», transformándose en $u$ explica el empleo de la grafía «Marturell».

SCRIPTA, Revista internacional de literatura i cultura medieval i moderna, núm. 9 / juny 2017 / pp. 113-143

ISSN: 2340 - 4841 doi:10.7203/SCRIPTA.9.10214 
Agustín Rubio Vela. Militares, cortesanos y poetas en el entorno de los infantes de Aragón (14391445): las Coplas de Juan de Dueñas al infante don Enrique

Algún escribiente castellano habría leído erróneamente «martel» en lugar de «mart[ur]el», dando pie a un linaje inexistente. Explicamos a continuación las razones que nos llevan a proponer esta hipótesis.

En primer lugar, conviene recordar la alusión al «gentil de Marturel, más galán que Leonel», en un poema castellano del Cuatrocientos: la «Respuesta» dada por Mendo Chamiso a «El mote que vende Contreras», que se ha considerado una posible referencia a Joanot Martorell: «Acaso algún incidente [...] de los muchos que debió protagonizar el genial escritor, dio pie a ese guiño irónico de Chamiso», escribe Ana Ma Álvarez Pellitero, que ubicó cronológicamente el cancionero del que forma parte la composición «hacia 1440 [...], en el medio de un margen que oscilaría entre 1437 y 1442» (1993: XIII). Independientemente de la identificación, la alusión da cuenta de la presencia en Castilla de un «Marturel» que se desenvolvía en un ambiente militar, que —añadimos nosotrosparece relacionado con el infante Enrique, puesto que el Mendo Chamiso de la chispeante respuesta en que supuestamente se cita al valenciano era miembro de la orden de Santiago, según consta en las actas del capítulo celebrado en 1440 en Uclés, presidido por el infante. En ellas se alude en varias ocasiones, entre los freires y caballeros convocados que no acudieron a su llamamiento, a «Mendo Chamizo, comendador de Los Santos» (Ostos Salcedo 2008: 383, 395 y 397).

Por otro lado, es sabido que Joanot Martorell no fue persona ajena a don Enrique. Su vinculación el futuro autor de Tirant lo Blanch es bien conocida. Cuando éste batalló epistolarmente con Joan de Montpalau en 1437, el nombre del infante, residente entonces en la ciudad de Valencia, aparece una y otra vez en esa célebre correspondencia. No sólo porque las cartas de batalla que se cruzaron fueron llevadas por Desirós, el porsevante de aquél («vos tramet la present per Desirós, porsavant del molt il lustre senyor lo senyor inffant don Enrich...»; «Per Desirós, porsavat del molt il lustre senyor lo infant don Enrich, he rebuda una vostra letra...»), sino porque el infante fue nombrado «indiferent o tercer» por los seis mediadores designados por los rivales. Obligado, en virtud del nombramiento, a tomar ciertas decisiones sobre aspectos de la batalla que tendrían que librar Martorell y Montpalau, don Enrique se dio un plazo de cinco meses. Excesivo, a juicio de Montpalau, que responsabilizó a Joanot de haber propiciado la "gran dilació dels cinch mesos», si bien acató la decisión, "per reverència del senyor Infant», no sin manifestar cuáles eran sus intenciones «si dins los $\cdot \mathrm{V} \cdot$ mesos per lo senyor Infant no y haurà pronunciat» (Riquer 1972: 38, $41,45,51,56,58,61,63,66,70,73-83,86,90,93,94,98-104)$.

El 22 de marzo del año siguiente, Joanot estaba en Londres. Había viajado sin permiso del infante, lo cual apunta a una relación personal, a algún vínculo del futuro novelista con la casa de don Enrique. Casa en el sentido de «núcleo presidido por el señor e integrado por él y su amplio grupo de dependientes», donde se ejerce el poder político señorial (Sáiz 2006: 98-99). Desde Inglaterra, tras haber conseguido que el propio rey Enrique VI fuese juez del encuentro, requirió la presencia de Montpalau para llevar a cabo un combate que, como es sabido, no llegó a realizarse, pues un prohombre valenciano, Perot Mercader, «en calidad de emisario del infante de Aragón»—de nuevo 
Agustín Rubio Vela. Militares, cortesanos y poetas en el entorno de los infantes de Aragón (14391445): las Coplas de Juan de Dueñas al infante don Enrique

aparece don Enrique de Trastámara-, se presentó ante el monarca y le mostró los documentos de un acuerdo alcanzado en Valencia por las dos familias, la de Montpalau y la de Martorell, en relación al asunto que desencadenó la enemistad, con lo que ya no había motivo para la lucha. En consecuencia, el 14 de febrero de 1439, el soberano inglés escribió al infante aragonés una misiva en la que le daba cuenta de que había desconvocado el combate, elogiaba a Martorell y le pedía que lo mantuviera en su afecto. Un día antes, el bregoso Joanot retaba a «batalla a ultrança» a Mercader, al que acusaba de haber dicho que él se había marchado a Inglaterra sin permiso del infante, a quien llama «mon príncep» en uno de los párrafos de la misiva: «no és offici de cavaller ni de misatger que ve de part d'un tal notable príncep com és lo senyor infant don Enrich; car vós haveu dit en presència de alguns notables senyors e cavallers que yo he feyt falta a mon príncep per ço com me'n seria vengut sens licència» (Riquer 1972: 107-110).

¿Pudo encaminarse a Castilla tras estos episodios? ¿Pudo ser él el enigmático «Martel» de las Coplas? A nuestro juicio, en caso de que se tratara del apellido Martorell mal copiado, es más verosímil que correspondiera a la persona, no del novelista, sino de su hermano Jaume, por estar éste vinculado a Juan de Navarra, de quien era «uixer d'armes». En tres ocasiones, los días 24 de abril, y 1 y 5 de 1437, actuó en las cortes valencianas, no como miembro de la asamblea parlamentaria, sino como testigo de actos realizados en ella: "Testes sunt qui ad presentes fuerunt [...] Iacobus Martorell, uxerius armorum dicti domini regis locumtenentis». ${ }^{35}$ Consideramos de interés indicar que en las actas de esas cortes aparecen dos personas mencionadas en las Coplas: Rui Díaz de Mendoza, que figura en una larga lista de firmantes de una petición suscrita igualmente por Jaume Martorell y tres de sus hermanos, ${ }^{36}$ y Rodrigo de Rebolledo, que en la sesión del 20 de mayo de 1438 actúa de testigo: «Testes fuerunt ad premissa presentes Rodericus de Rebolledo, camerarius maior [...] dicti domini regis locumtenentis». ${ }^{37}$

Hay otros datos que relacionan a Jaume Martorell con el futuro Juan II de Aragón y con los hombres de su entorno. Entre 1448 y 1450, cuando Calp, que había sido transferida por Juan de Navarra al fiel Rebolledo, volvió a ser patrimonio de la monarquía, Jaume Martorell, convertido ya en alguacil real, sucedió en el cargo de recaudador y administrador de las rentas de aquella localidad a otro hombre de confianza del rey de Navarra, Pere Verdeguer (Llopis Bertomeu 1953: 63; Campón y

35 AMV, Procesos de cortes yy-15, ff. 93v-94r, 140r y 147v.

36 Por el siguiente orden; entre los caballeros, «mossén Galceran Martorell» y «mossén Roy Díez de Mendoça»; después, entre los «gentils hòmens», «En Johanot Martorell», «En Joffre Martorell, En Jacme Martorell» (AMV, Procesos de cortes yy-15, ff. 144v y 145v). El profesor Torró se ha referido a ello: «si llegim els processos d'aquestes corts [...] trobarem junts a València [...] els infants Joan i Enric, Diego Gómez de Sandoval, comte de Dénia; Ruy Díaz de Mendoza, cambrer major de Joan d'Aragó [...]; Galceran Martorell, Joanot Martorell y Jaume Martorell, donzell, uixer d'armes de Joan de Navarra, entre els més coneguts per raó de les lletres» (Torró 2009: 20-22).

37 AMV, Cortes, yy-15, f. 272r.

SCRIPTA, Revista internacional de literatura i cultura medieval i moderna, núm. 9 / juny 2017 / pp. 113-143 ISSN: 2340 - 4841 doi:10.7203/SCRIPTA.9.10214 
Agustín Rubio Vela. Militares, cortesanos y poetas en el entorno de los infantes de Aragón (14391445): las Coplas de Juan de Dueñas al infante don Enrique

Pastor 1989: 147 y 149). ${ }^{38}$ Y sabemos, por otro lado, que, en su condición de lugarteniente, don Juan benefició a Jaume en detrimento del también alguacil Perot Pardo de la Casta, hasta el punto de provocar en 1453 la protesta de los jurats valencianos (Rubio Vela 2013: 133).

Un nuevo favor se documenta años más tarde. Una irregular rendición de cuentas de Jaume Martorell ante el maestre racional al término de su administración en el señorío de Calp, dio lugar, en el verano de 1459, a un problema que Juan II, ya rey de Aragón, resolvió en favor de su protegido. ${ }^{39} \mathrm{El}$ maestre racional, considerando que Martorell debía dinero al erario real, había ordenado embargar sus bienes; una medida que no se llevó a cabo porque el rey, a súplicas del que había sido administrador del castillo y término de Calpe, la sobreseyó: «que fos sobresehit en la execucio que's fahie contra mossen Jacme Martorell, algutzir nostre, axi com a olim receptor de les rendes, fruyits e emolumens del loch e terme de Calp per raho de les comptes per aquell donats en vostre offici». Ordenó asimismo al maestre racional que admitiera las partidas que había rechazado, y, a fin de que Martorell pudiese devolver el dinero que aún debía, se le permitía recuperar el que le era adeudado a él en Calpe, por entregas y préstamos realizados durante su administración. ${ }^{40}$

Así pues, en el entorno de los infantes de Aragón, nadie llamado Martel aparece, pero sí dos hermanos de la familia Martorell: Joanot y Jaume. No es extraño que uno —el segundo tal vez, y dicho sea con todo tipo de cautela - fuera la persona que, con nombre equivocado, enviara saludos a Enrique de Aragón en las Coplas de Dueñas, junto a personalidades como Fernando de Rojas Sandoval, Rodrigo de Rebolledo o Diego Fajardo, que poseyeron en el reino de Valencia dominios territoriales gracias al favor de Juan de Navarra. ${ }^{41}$

38 Cuando cedió a su hijo Carlos, príncipe de Viana, el ducado de Gandia, el rey de Navarra siguió controlándolo por medio de Verdeguer, a quien nombró procurador general. En 1445, le escribían los ediles de Valencia: «Al molt honorable e savi mossènyer En Pere Verdeguer, procurador general per lo senyor príncep de Navarra en la vila de Gandia» (AMV, Lletres Missives 20, f. 232r-v; 1445, enero, 8).

39 A este episodio se han referido Llopis Bertomeu 1953: 62-64 y 266-267; Campón y Pastor 1989: 149; y Cruselles 1989: 79 y 207-208.

40 El documento, fechado en Segorbe el 14 de agosto de 1459, fue publicado por Llopis Bertomeu (1953: 266-267), lo que no debía saber Cruselles cuando hizo el regesto (1989: 208, doc. núm. 156).

41 Un mossén Joan Martorell, caballero, que a nuestro juicio podría ser el novelista, fue procurador general del condado de Dénia tras ser restituido a los Sandoval (Rubio Vela 2010: 31-39, 49-55 y 67-69). La familia Castellví también siguió relacionada con éstos. En 1477, cuando Fernando de Rojas Sandoval, segundo conde de Castro, recuperó el castillo de Dénia, fue un miembro de aquel linaje, el «magnífich mossen Francesch de Castellvi, cavaller», quien actuó en el acto «com a procurador del spectable comte de Castro» (Chabás 1985: 296). 
Agustín Rubio Vela. Militares, cortesanos y poetas en el entorno de los infantes de Aragón (14391445): las Coplas de Juan de Dueñas al infante don Enrique

\section{Bibliografía}

Alonso, Álvaro (ed.) (2006) Poesía de Cancionero, Madrid, Cátedra, $6^{a}$ ed.

Álvarez Pellitero, Ana Ma. (ed.) (1993) Cancionero de Palacio. Ms. 2653 Biblioteca Universitaria de Salamanca, Salamanca, Junta de Castilla y León.

Amador de los Ríos, J. (1871-1872), «La poesía política en el siglo XV, la privanza y el suplicio del condestable don Álvaro de Luna», Revista de España, XXIV, pp. 550-569, y XXV, pp. 44-70 y 337-364.

Avalle-Arce, Juan B. (1972), El cronista Pedro de Escavias. Una vida del siglo XV, Chapel Hill, The University of North Carolina Press.

Azáceta, J. Ma . (ed.) (1966) Cancionero de Juan Alfonso de Baena, Madrid, CSIC, 3 vols.

Barrio Sánchez, J. A. (ed.) (1998) Fernán Pérez de Guzmán: Generaciones y semblanzas, Madrid, Cátedra.

Benito Ruano, E. (1952) Los infantes de Aragón, Madrid, CSIC.

- (1994) Tirant lo Blanch, novela de historia y de ficción, Barcelona, Círculo de Lectores. (1964) «Fortuna literaria del Infante D. Enrique de Aragón», Archivum, XIV, pp. 161-201.

Blasco de Lanuza, Vincenzio (1622) Historias ecclesiasticas y seculares de Aragon, en que se continnuan los Annales de Curita, desde el Año 1556 hasta el de 1618. Tomo segundo, Zaragoza, Juan de Lanaja y Quartanet.

Cabrera, Emilio (2001) «Andalucía y los infantes de Aragón», Acta bistorica et archaeologica mediaevalia, 22, pp. 699-720.

Campón Gonzalvo, Júlia, \& Pastor Fluixà, J. (1989), Nuevas aportaciones a la Història de Calp, Ajuntament.

Carriazo, Juan de M. (ed.) (1940) Crónica de don Álvaro de Luna, condestable de Castilla, maestre de Santiago, Madrid, Espasa-Calpe.

(ed.) (1994) Tirant lo Blanch, novela de bistoria y de ficción, Barcelona, Círculo de Lectores.(ed.) (1946-a) Crónica del Halconero de Juan II, Pedro Carrillo de Huete, Madrid, Espasa-Calpe.

- (1994) Tirant lo Blanch, novela de bistoria y de ficción, Barcelona, Círculo de Lectores. (ed.) (1946-

b) Refundición de la crónica del Halconero, por el obispo don Lope Barrientos, Madrid, Espasa-Calpe.

- (1994) Tirant lo Blanch, novela de bistoria y de ficción, Barcelona, Círculo de Lectores.(ed.) (1953), «Los Anales de Garci Sánchez, jurado de Sevilla», Anales de la Universidad Hispalense, XIV, pp. 3-63.

Chabás, Roque (1985) Historia de la ciudad de Denia. Notas introductorias de Manuel Bas y José Carrasco, Alicante, Diputación provincial de Alicante, Ayuntamiento de Denia.

Croce, Benedetto (2007) España en la vida italiana del Renacimiento, Sevilla, Renacimiento.

Cruselles, Enrique (1989) El maestre racional de Valencia. Función politica y Desarrollo Administrativo del Oficio Público en el siglo XV, Valencia, Edicions Alfons el Magnànim. 
Agustín Rubio Vela. Militares, cortesanos y poetas en el entorno de los infantes de Aragón (14391445): las Coplas de Juan de Dueñas al infante don Enrique

Desdevises du Dezert, G. (1889) Don Carlos d'Aragon, prince de Viane. Étude sur l'Espagne du nord au XVe siècle, París, Armand Colin.

Dutton, Brian (1990-1991) El cancionero del siglo XV, c. 1360-1520, Universidad de Salamanca, 7 vols.

Ferrando, Antoni (1999) «L'anònim Pròleg d'una no poc devota adoració de Jesús crucificat. una mostra de la prosa artitzada de les darreries del segle XV», en Vicent Martines, ed., Estudis sobre Joan Roís de Corella, Alcoi, Ed. Marfil, pp. 133-156.

Garcia, Michel (1970) «Carta delas nueuas de quando fueron vençidos los valençianos la qual enbio el adelentado de castilla al dicho Rey don ferrnando», Atalaya, El historiador en su taller, http:// atalaya.revues.org/index122.html.

- (1994) Tirant lo Blanch, novela de bistoria y de ficción, Barcelona, Círculo de Lectores. (ed.) (1972) Repertorio de príncipes de España y obra poética del alcaide Pedro de Escavias, Jaén, Instituto de Estudios Giennenses del CSIC.

Garcia-Oliver, F., Aparisi, F., Rangel, N., y Royo, V. (eds.) (2009-2011) Hug de Cardona. Col Hecció diplomàtica (1407-1482), Universitat de València, Fonts històriques valencianes, 3 vols.

Vidal González, F. (ed.) (2003) Gómez Manrique: Cancionero, Madrid, Cátedra.

Gual Camarena, M. (1951) Las treguas de Majano entre Aragón, Navarra y Castilla (1430), Buenos Aires, Facultad de Filosofía y Letras.

Hinojosa Montalvo, J. (2015) «Rebolledo: Un linaje castellano en el reino de Valencia a fines de la edad media», Estudios de historia de España, vol.17, n.2 [on line].

Jiménez de la Espada, M. (ed.) (1995), Andanzas y viajes de un hidalgo español, Madrid, Biblioteca de Viajeros Hispánicos, 13, Miraguano Ediciones, Ediciones Polifemo.

Kerkhof, M. P. A. M., y Gómez Moreno, A., eds. (2003), Marqués de Santillana: Poesías completas, Madrid, Clásicos Castalia.

Olivera Serrano, C. (ed.) (2016) Documentos sobre Enrique IV de Castilla y su tiempo Vol. I, Madrid, Universidad Carlos III.

Llopis Bertomeu, V. (1953) Calpe, Valencia, Imprenta J. Nácher.

López Rodríguez, C. (2005) Nobleza y poderpolitico en el reino de Valencia (1416-446), Universitat de València.

Madurell Marimón, J. Ma (1963) Mensajeros barceloneses en la corte de Nápoles de Alfonso $V$ de Aragón, 1435-1458, Barcelona, CSIC.

Marino, Nancy (1985) «Un exilio político en el siglo XV. El caso del poeta Juan de Dueñas», Cuadernos Hispanoamericanos, núm. 416, pp. 139-151.

Méndez Apénela, E. (2004) «Mosén Diego Fajardo», Murgetana, 110, pp. 23-42.

Mota, Carlos (1997) «El condestable en su laberinto: memoria literaria de Ruy López Dávalos», Actes del VII Congrés de l'Associació Hispànica de Literatura Medieval, Castelló de la Plana, pp. 49-62.

SCRIPTA, Revista internacional de literatura i cultura medieval i moderna, núm. 9 / juny 2017 / pp. 113-143

ISSN: 2340 - 4841 doi:10.7203/SCRIPTA.9.10214 
Agustín Rubio Vela. Militares, cortesanos y poetas en el entorno de los infantes de Aragón (14391445): las Coplas de Juan de Dueñas al infante don Enrique

Ostos Salcedo, Pilar (2008) La orden de Santiago y la escritura. El valor de la comunicación escrita en una orden militar. Los establecimientos de 1440, Universidad de León.

Rico, Francisco (1990) «Unas coplas de Jorge Manrique y las fiestas de Valladolid en 1428», en Texto y contextos. Estudios sobre la poesía española del siglo XV, Barcelona, Crítica, pp. 169-187.

Riquer, Martín de (1965) Vida caballeresca en la España del siglo XV, Madrid, Real Academia Española.

—. (1994) Tirant lo Blanch, novela de historia y de ficción, Barcelona, Círculo de Lectores.

Riquer, Martín de, \& Vargas Llosa, M. (1972) El combate imaginario. Las cartas de batalla de Joanot Martorell, Barcelona, Barral Editores.

Rius Serra, J. (1927) Catalanes y aragoneses en la corte de Calixto III, Barcelona, Biblioteca Balmes.

Rodrigo Lizondo, M. (ed.) (2011) Melcior Miralles: Crònica i dietari del capellà d'Alfons el Magnánim, Fonts històriques valencianes, Universitat de València.

Rosell, Cayetano (ed.) (1953), Crónica del rey don Juan el Segundo, en Crónicas de los reyes de Castilla. Desde don Alfonso el Sabio hasta los Católicos don Fernando y doña Isabel, II, Madrid, Biblioteca de Autores Españoles, LXVIII, pp. 273-695.

Rubio Vela, A. (2003) «Urgelistas valencianos. Sobre la oposición a Fernando I de Trastámara», Anuario de Estudios Medievales, 33/1, pp. 191-261.

—. (2010) Joanot Martorelly el condado de Dénia. Una clave en el Tirant, Valencia, Gráficas Papallona.

- (2013) «L'escrivà de ració del príncep de Viana i l'autoria del Tirant lo Blanch. Notes de crítica documental a l'entorn d'un miratge literari», en Germà Colón Doménech (ed.), Els escriptors valencians del segle XV, Castelló de la Plana, Universitat Jaume I, pp. 109-137.

Sáiz Serrano, Jorge (2008) Caballeros del rey. Nobleza y guerra en el reinado de Alfonso el Magnánimo, Valencia, Universitat de València.

Salvador Miguel, N. (1977) La poesía cancioneril. El Cancionero de Estúñiga, Madrid, Alhambra.

Sánchez-Parra, Ma Pilar (ed.) (1991) Crónica anónima de Enrique IV de Castilla 1454-1474 (Crónica castellana), Madrid, Ediciones de la Torre.

Sans i Travé, J. M. (1992) Dietari o Llibre de Jornades (1411-1484) de Jaume Safont, Barcelona, Fundació Noguera.

Sarasa, Esteban (2009) «La alta nobleza laica aragonesa entorno a los Trastámara (siglo XV)», en $\mathrm{M}^{\mathrm{a}}$ José Casaus Ballester, ed., El Condado de Aranda y la nobleza española en el Antiguo Régimen, Zaragoza, Institución «Fernando el Católico», pp. 9-30.

Silió, César (1935) Don Álvaro de Luna y su tiempo, Madrid, Espasa Calpe.

Solano Costa, F. (1970) Notas para una biografía del arzobispo don Juan de Aragón, administrador de la archidiócesis de Zaragoza (1439?-1475?). Discurso de ingreso en la Real Academia de nobles y bellas artes de San Luis, Zaragoza, Institución «Fernando el Católico». 
Agustín Rubio Vela. Militares, cortesanos y poetas en el entorno de los infantes de Aragón (14391445): las Coplas de Juan de Dueñas al infante don Enrique

Suárez Fernández, L. (2002) Enrique IV de Castilla. La difamación como arma política, Barcelona, Ariel, $3^{\mathrm{a}}$ ed. - (2005) Nobleza y monarquía. Entendimiento y rivalidad. Elproceso de construcción de la Corona española, Barcelona, La esfera de los libros.

Tate, B., \& Lawrance, J. (eds.)(1998-1999), Alfonso de Palencia: Gesta hispaniensia ex annalibus suorum dierum collecta, Madrid, Real Academia de la Historia, 2 vols.

Torró, Jaume, (ed.) (2009) Lluis de Requesens, Bernat Miquel, Martí Garcia, Rodrigo Dies, Lluís de Vilarasa, Francesc Sunyer. Sis poetes del regnat d'Alfons el Magnànim, Barcelona, Barcino.

- (ed.) (2010) «Els darrers anys de Joanot Martorell.» Regesta documental presentada en el Congreso Internacional Tirant lo Blanch 250 anys (1490-2010), 17 de setembre de 2010.

Vendrell de Millás, Francisca (1945) El cancionero de Palacio (Manuscrito n. 594), Barcelona, CSIC.

_. (1958) «Las poesías inéditas de Juan de Dueñas», Revista de Archivos, Bibliotecas y Museos, LXIV,1, pp. 149-240.

Vicens Vives, J. (2003) Juan II de Aragón (1398-1479): monarquía y revolución en la España del siglo XV, ed. de P. H. Freedman y J. M. Muñoz i Lloret, Pamplona, Urgoiti editores.

- (2006) Historia crítica de la vida y reinado de Fernando II de Aragón, ed. de Miquel A. Marín Gelabert, Zaragoza, Institución «Fernando el Católico». 